\title{
A behavioral analysis of the volatility of interbank interest rates in developed and emerging countries
}

\author{
Nara Rossetti \\ Department of Production Engineering, Federal University of São Carlos, \\ Sorocaba, Brazil \\ Marcelo Seido Nagano \\ Department of Production Engineering, Universidade de São Paulo, \\ São Carlos, Brazil, and \\ Jorge Luis Faria Meirelles \\ Department of Production Engineering, Federal University of São Carlos, \\ Sorocaba, Brazil
}

Interbank
interest rates

Received 27 August 2015 Revised 26 January 2017 Accepted 15 March 2017

\begin{abstract}
Purpose - This paper aims to analyse the volatility of the fixed income market from 11 countries (Brazil, Russia, India, China, South Africa, Argentina, Chile, Mexico, USA, Germany and Japan) from January 2000 to December 2011 by examining the interbank interest rates from each market.

Design/methodology/approach - To the volatility of interest rates returns, the study used models of auto-regressive conditional heteroscedasticity, autoregressive conditional heteroscedasticity (ARCH), generalized autoregressive conditional heteroscedasticity (GARCH), exponential generalized autoregressive conditional heteroscedasticity (EGARCH), threshold generalized autoregressive conditional heteroscedasticity (TGARCH) and periodic generalized autoregressive conditional heteroscedasticity (PGARCH), and a combination of these with autoregressive integrated moving average (ARIMA) models, checking which of these processes were more efficient in capturing volatility of interest rates of each of the sample countries.

Findings - The results suggest that for most markets, studied volatility is best modelled by asymmetric GARCH processes - in this case the EGARCH - demonstrating that bad news leads to a higher increase in the volatility of these markets than good news. In addition, the causes of increased volatility seem to be more associated with events occurring internally in each country, as changes in macroeconomic policies, than the overall external events.
\end{abstract}

Originality/value - It is expected that this study has contributed to a better understanding of the volatility of interest rates and the main factors affecting this market.

Keywords Volatility, Emerging countries, ARCH-GARCH models, Fixed income

Paper type Research paper

(C) Nara Rossetti, Marcelo Seido Nagano and Jorge Luis Faria Meirelles. Published in Journal of Economics, Finance and Administrative Science. Published by Emerald Publishing Limited. This article is published under the Creative Commons Attribution (CC BY 4.0) licence. Anyone may reproduce, distribute, translate and create derivative works of this article (for both commercial and non-commercial purposes), subject to full attribution to the original publication and authors. The full terms of this licence may be seen at http://creativecommons.org/licences/by/4.0/legalcode

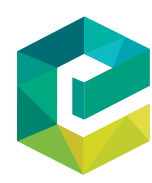

Journal of Economics, Finance and Administrative Science Vol. 22 No. 42, 2017 pp. $99-128$
pol. 22 No. 42,217 Emerald Publishing Limited 2077-1886 DOI 10.1108/JEFAS-02-2017-0033 
Propósito - Este estudio analiza la volatilidad del mercado de renta fija de once países (Brasil, Rusia, India, China, Sudáfrica, Argentina, Chile, México, Estados Unidos, Alemania y Japón) de enero de 2000 a diciembre de 2011, mediante el examen de las tasas de interés interbancarias de cada mercado.

Diseño/metodología/enfoque - Para la volatilidad de los retornos de las tasas de interés, se utilizaron modelos de heteroscedasticidad condicional autorregresiva: ARCH, GARCH, EGARCH, TGARCH y PGARCH, y una combinación de estos con modelos ARIMA, comprobando cuáles de los procesos eran más eficientes para capturar la volatilidad de interés de cada uno de los países de la muestra.

Hallazgos - Los resultados sugieren que para la mayoría de los mercados estudiados la volatilidad es mejor modelada por procesos GARCH asimétricos — en este caso el EGARCH— demostrando que las malas noticias conducen a un mayor incremento en la volatilidad de estos mercados que las buenas noticias. Además, las causas de una mayor volatilidad parecen estar más asociadas a eventos que ocurren internamente en cada país, como cambios en las políticas macroeconómicas, que los eventos externos generales.

Originalidad/valor - Se espera que este estudio contribuya a un mejor entendimiento de la volatilidad de las tasas de interés y de los principales factores que afectan a este mercado.

Palabras clave - Ingreso fijo, Volatilidad, Países emergentes, Modelos ARCH-GARCH

Tipo de artículo - Artículo de investigación

\section{Introduction}

The main goal of most macroeconomic policies is the continuous growth of the gross domestic product in conjunction with low inflation, so the maintenance of price stability has a significant role in the economic growth rate (Nguyen, 2015). Among macroeconomic policies, monetary policy is responsible for liquidity control within the economic system, and the main instrument of this policy is the control of interest rates.

Thus, changes in monetary policy can lead to changes in interest rates. According to Karagiannis et al. (2010), monetary policy is one of the two main tools in standard economic theory that governments can use to influence production, investment, prices and employment in the economy. Monetary policy can affect the main macroeconomic variables through three channels: interest rate, bank loans and credit expansion.

When the Central Bank has adopted a tight monetary policy, i.e. raising the interest rate causes an increase in funding costs of banks and thus a reduction in loan growth (Macit, 2012). The adjustment of retail bank interest rates (deposit and loan rates) in response to changes in wholesale rates (central bank and interbank money market rates) is a key element in the transmission mechanism of the interest rate. In an effective monetary policy, any change in the interest rate charged by the central bank must be transmitted to interest rates in the retail (consumer) market and will influence business loan rates, thereby affecting domestic aggregate demand and production (Karagiannis et al., 2010).

The purchase and sale of government securities is one means of controlling the money supply; for example, when there is excess money in circulation, selling government securities can help remove currency from the market, whereas purchasing government securities can help inject capital into the economy. According to Mankiw (2005), monetary policy "can be described either in terms of the money supply or in terms of the interest rate". Mankiw (2005) uses the example of the US Federal Open Market Committee (FOMC), to illustrate this point: when the FOMC sets a target for the interest rate, public debt securities traders will perform all possible open market operations to ensure that the equilibrium interest rate equals the target set by the FOMC, which adjusts the money supply accordingly.

Interbank interest rates are the basis of interbank market operations. When purchasing a bank's deposit certificate, an investor becomes a creditor of this institution, turning this security into a fixed income asset. 
The fixed income concept, according to Haugen (1997), is that receipts will never exceed the initially agreed upon value, although this value can be lower in the case of default because these assets have certain scheduled payments, according to Pinheiro (2009), and investors thus know cash flows in advance. These fixed income securities are called bonds.

Fabozzi (2000) posits that bonds are a debt instrument pursuant to which issuers (debtors) are obligated to pay investors (lenders) the amount borrowed plus interest. When a bond pays periodic interest, these payments are referred to as coupons.

Fixed income assets can be classified into two types:

(1) fixed-rate, in which the coupon is established at the time the bond is acquired because the interest rate is fixed over the bond payment period; and

(2) floating-rate, in which the coupon payment varies according to the variation of a predetermined indexing rate, which can be the interbank interest rate or an inflation index, for example.

In the fixed income market, investors seek assets that provide immediate liquidity and the maximum possible protection for their portfolios. In the Brazilian fixed income market, for example, high interest rates (which are typical in high inflation years) can make long-term fixed-rate securities unattractive, due to their implied higher risk. Thus, because it has a floating rate, the one-day interbank deposit certificate (CDI) was eventually chosen as the benchmark in this market. According to the BM\&FBOVESPA (2011), "the CDI acquired the role of a quasi-currency for most economic agents".

According to Gertler and Karadi (2010), the Federal Reserve manipulated the federal funds rate to implement monetary policy by affecting market interest rates during most of the post-war period, thus avoiding making loans directly into private markets. For Gertler and Karadi (2010), the situation changed dramatically after the beginning of the subprime crisis, when countries were forced to adopt and implement two types of emergency economic policies to minimize the effects of the crisis: monetary policies and policies involving the intervention of financial institutions (Acioly et al., 2010).

In choosing to aim to minimize the impact of the financial crisis with the second option, the federal reserve system (FED) injected credit directly into the private markets, when it allowed financial institutions to obtain discounts in the exchange of government debt securities for high-risk private securities. Following the bankruptcy of Lehman Brothers, the FED began a series of more dramatic interventions in the financial system, such as by lending money in high-credit risk markets, helping revitalize the commercial paper market and buying mortgage-backed debts (Gertler and Karadi, 2010).

According to Krugman and Obstfeld (1999), increasing a country's money supply leads its currency to depreciate in the foreign exchange market because an increased money supply increases the economy's liquidity and depreciates its currency as a result of a higher price level. Thus, the country's currency depreciates against the currency of other countries in the foreign exchange market. To avoid this effect, the central bank may raise interest rates to reduce liquidity and generate currency appreciation in the foreign exchange markets.

This paradigm demonstrates that controlling the interest rate becomes the nation's main monetary policy instrument, which leads central banks to use this mechanism to control liquidity levels in the economy in terms of both domestic and foreign currencies. One way to analyse the performance of these variables is by analysing market volatility, which represents a risk measure because it is the conditional variance of a security return. Knowing the past (historical) volatility of returns and the methods for forecasting asset volatility is essential to allocating funds in a portfolio and can be one way to identify the characteristics of different markets. 
JEFAS

22,42

102
Thus, this study aims to analyse the volatility of fixed income market returns in the BRICS countries (Brazil, Russia, India, China and South Africa), three Latin American countries (Argentina, Chile and Mexico) and three developed countries (the USA, Japan and Germany). This analysis seeks to establish which of the autoregressive conditional heteroscedasticity (ARCH), generalized autoregressive conditional heteroscedasticity (GARCH), exponential generalized autoregressive conditional heteroscedasticity (EGARCH), threshold generalized autoregressive conditional heteroscedasticity (TGARCH) and periodic generalized autoregressive conditional heteroscedasticity (PGARCH) models and which combination thereof with autoregressive integrated moving average (ARIMA) models is the most efficient for modelling the volatility structure of interbank interest rates in these countries.

The choice of countries in the survey is made with the following reasoning. In addition to being geographically close, the Latin American countries have similar economic and financial characteristics. The countries comprising BRICS are part of a "bloc" created by economist Jim O'Neill in 2001 to describe the major emerging countries of the world (South Africa was the last to join the bloc in 2011), and developed countries were chosen according to the World Bank (2011).

This paper is divided into five sections. This section is an introduction that contextualizes and justifies the study's topic and presents its objective. Section 2 presents a literature review on the volatility of financial assets. Section 3 describes the research methodology, and Section 4 presents the results found in the models developed herein. Finally, Section 5 discusses the final considerations of the study.

\section{Literature review}

For Alexander (2005), asset prices can be observed now and in the past, but it is not possible to determine how these same prices will behave in the future because asset prices are random variables (stochastic) and non-deterministic. According to Taylor (2005), the speed at which asset prices change is called volatility, and for Wilmott (2001), volatility is how fluctuations in the price of an asset are measured and are therefore a risk measure. The risk is associated with the uncertainty regarding the return on assets, and return is the price fluctuation that these assets experience.

Enders (2004) adds that knowledge of the dynamics of a series provides a more accurate forecast, provided that each of the expected components can be extrapolated into the future.

According to Alexander (2005), relative changes in prices are typically measured by the difference in the logarithm of prices that have a normal distribution.

Thus, the return on an asset price can be defined as the following (Fama, 1965):

$$
r_{t}=\log _{e} p_{t+1}-\log _{e} p_{t}
$$

where $r_{\mathrm{t}}$ is the return on securities, $p_{t}$ is the security price in period $t$ and $p_{t+1}$ is the security price in a subsequent period.

In economic and financial series, the asset price behaviour is not typically constant over a long period. Prices respond to internal and external changes in macroeconomic variables and other events that generate insecurity for portfolio managers and investors.

According to Stock and Watson (2004), in economic time series, some periods are more stable than others because series volatility occurs in clusters. These clusters are called conditional heteroscedasticity because they determine that the error shows heteroscedasticity that varies over time.

The most commonly known volatility clustering models include autoregressive conditional heteroscedasticity models developed by Engle (1982) and the generalization of this model, GARCH models, developed by Bollerslev (1986). 
According to Alberg et al. (2008), autoregressive conditional heteroscedasticity models are econometric tools used to estimate and predict the volatility of returns on assets.

Thus, according to Engle (1982), an ARCH model is given by:

$$
\sigma_{t}^{2}=\alpha_{0}+\alpha_{1} e_{t-1}^{2}+\ldots+\alpha_{p} e_{t-p}^{2}
$$

where variance $\sigma_{t}^{2}$ depends on the square of past values of $e_{t}$ (the residuals of a model fitted to the mean in a stationary process, under traditional assumptions of linear regression models), $\alpha_{1}, \alpha_{2}, \ldots$ and $\alpha_{p}$ are unknown coefficients and $p$ is the order of the ARCH process.

In an ARCH model, the error structure is such that the conditional and unconditional mean is equal to zero because the conditional variance is already an autoregressive process resulting in conditionally heteroscedastic errors. Thus, the ARCH model captures periods of stability and high volatility in $y_{t}$ series (Enders, 2004).

Alexander (2005) states that the ARCH model with exponentially decreasing coefficients is equivalent to a $\operatorname{GARCH}(1,1)$ model because $\mathrm{ARCH}(\mathrm{p})$ models converge to a $\mathrm{GARCH}(1,1)$ model as $p$ increases.

Bollerslev (1986) demonstrates that the GARCH model allows a longer-term memory and more flexible lag structure, which means that the complete GARCH (p, q) model adds q autoregressive terms to the ARCH specification (p), according to Alexander (2005), and is expressed by the following:

$$
\alpha_{t}^{2}=\alpha_{0}+\sum_{i=1}^{p} \alpha_{i} \varepsilon_{t-1}^{2}+\sum_{i=1}^{q} \beta_{i} \alpha_{t-1}^{2}
$$

where:

$$
\begin{aligned}
& q \geq 0 ; p>0 \\
& \alpha_{0}>0 ; \alpha_{i} \geq 0, i=1, \ldots, p \\
& \beta_{i} \geq 0, i, i=1, \ldots, q
\end{aligned}
$$

For $q=0$, the process is reduced to an $\mathrm{ARCH}(p)$ model, and for $p=q=0$, it is simply white noise. Thus, the condition for the series to be stationary is that $\alpha_{1}+\beta_{1}<1$ (Bollerslev, 1986).

However, the symmetric GARCH, model does not capture the existing asymmetrical effects on variables in which the effects of negative shocks tend to be larger than the effects of positive shocks. According to Nelson (1991), GARCH models guarantee this condition by means of a linear combination of conditional variance, $\sigma_{t}^{2}$, (with positive weights) of positive random variables. The model developed by Nelson (1991), called EGARCH (exponential GARCH), is expressed as follows:

$$
\log \sigma_{t}^{2}=\omega+\alpha\left(\left|z_{t-1}\right|-E\left(\left|z_{t-1}\right|\right)\right)+\gamma z_{t-1}+\beta \log \sigma_{t-1}^{2}
$$

If $z_{\mathrm{t}}=\varepsilon \mathrm{t} \sigma-1$, the model captures the asymmetric effects between positive and negative shocks. For $\gamma<0$, negative shocks will have a greater impact on future volatility than positive shocks of the same magnitude (leverage effect) (Nelson, 1991; Bollerslev, 2008). According to Alexander (2005), some GARCH models require non-negativity constrained parameters to avoid generating negative variances, which does not occur in the case of EGARCH models because they consider the conditional variance in logarithmic terms.

In turn, the GJR-GARCH model developed by Glosten et al. (1993) allows the conditional variance to respond differently to positive and negative events, and its equation is given by:

$$
\sigma_{t}^{2}=\omega+\alpha \varepsilon_{t-1}^{2}+\gamma \varepsilon_{t-1}^{2} I\left(\varepsilon_{t-1}<0\right)+\beta \sigma_{t-1}^{2}
$$


JEFAS

22,42

104

where $I$ (.) corresponds to a function indicator. When the GJR model is estimated for stock index returns, $\gamma$ is found to be positive, such that the volatility increases on a proportionally larger scale in negative shocks than positive shocks. A closely related model to the GJR-GARCH is Zakoïan (1994). The TGARCH allows the conditional standard deviation to depend on the sign of events that have previously occurred, either positive or negative. The model is expressed by the following:

$$
\sigma_{t}=\omega+\alpha\left|\varepsilon_{t-1}\right|+\gamma\left|\varepsilon_{t-1}\right| I\left(\varepsilon_{t-1}<0\right)+\beta \sigma_{t-1}
$$

Another extension of the GARCH model that captures asymmetry by coefficient $\gamma$ is the PGARCH model of Ding et al. (1993), which is expressed by the following equation:

$$
\sigma_{t}^{\delta}=\omega+\sum_{i=1}^{p} \alpha_{i}\left(\left|\varepsilon_{t-i}\right|-\gamma_{i} \varepsilon_{t-i}\right)^{\delta}+\sum_{i=1}^{q} \beta_{j} \sigma_{t-i}^{\delta}
$$

where: $\delta>0 ; \omega>0 ; i=1, \ldots, p ;-1<\gamma<1$. According to the authors, coefficient $\delta$ (the exponent of conditional volatility) allows the long memory effect to be captured.

Other extensions of the ARCH and GARCH models have been developed to better capture asymmetric effects and long memory effects, in addition to being suitable for high frequency data. For additional information on these models, Bollerslev et al. (1998), Engle (1990), Higgins and Bera (1992), Engle and Kroner (1995), Baillie et al. (1996), Müller et al. (1997), Dacorogna et al. (1998) and Engle and Lee (1999).

Some studies have used the GARCH models and their extensions to model the volatility of interest rates, such as Reilly et al. (2000), Young and Johnson (2002), Young and Johnson (2005), Dihn and Nguyen (2008), Edwards and Susmel (2003), Goeu and Marquering (2004), Ke et al. (2008), Wet (2006), Andritzky et al. (2007) and Yang et al. (2009).

Although they have a higher level of volatility in their markets, emerging countries are the recipients of substantial foreign investments, which is due to greater economic stability and an increase in the debt financing of these countries, according to Polwitoon and Tawatnuntachai (2008), because they represent new opportunities for investors from other markets who are seeking high yields. Thus, debt securities (or the fixed income market) of emerging countries have been the subject of local and international investors and researchers interested in the behaviour of such assets.

In an analysis of the volatility ratio of sovereign debt in emerging countries and the volatility of global and regional markets, Dihn and Nguyen (2008) use the ARCH, GARCH and structural vector autoregressions (SVAR) models to find evidence that the global or regional market accounts for approximately 45 per cent of the variance of volatility changes in three of the five emerging countries selected in the study.

Edwards and Susmel (2003) analyse the volatility of interest rates in a group of Latin American countries (Argentina, Brazil, Mexico and Chile) and of Hong Kong in the 1990s using a markov switching autoregressive conditional heteroscedasticity (SWARCH) model. These authors find strong evidence of variation in the volatility of interest rates during the 1990s, but the periods of high volatility are short in duration, typically lasting from two to seven weeks.

According to Goeu and Marquering (2004), the results from a multivariate GARCH model demonstrate that the covariance between the returns on stocks and bonds tend to be relatively minor after bad news in the stock market and after good news in the bond market. Girard and Biwas (2007) add that the impact is felt on a larger scale by developed countries with respect to events that produce "bad news" in the market; this finding is echoed by Ke et al. (2008), who use the ARCH, GARCH, EGARCH and TGARCH volatility models and note that negative events generate higher volatility than positive events. 
In a study of the South African financial market, Wet (2006) analyses the volatility of three variables of a country - the stock index, the exchange rate and the interest rate - and uses a structural GARCH model to assess the influence of each variable on the others. Wet (2006) found in the South African market that the stock market index is significantly influenced by the interest rate, the exchange rate is influenced by the stock index but not by the interest rate and the interest rate is positively influenced by the other two variables.

Andritzky et al. (2007) use the GARCH model to examine how the bond markets of 12 emerging countries react to macroeconomic announcements and find that announcements about the ratings of these bonds and changes in the US interest rates have a greater effect on the volatility of the fixed income markets of these countries than announcements of local policies.

Through a bivariate GARCH-M model, Yang et al. (2009) analyse the US stock and bond markets by means of a temporal variation of the correlations over a period of 150 years (1855-2001), given macroeconomic conditions, and compare their results with the same variables from the UK: business cycle fluctuations, inflation environment and monetary policy (short-term interest rates). These authors conclude that the correlation between stocks and bonds is smaller during recessionary periods than during expansionary periods in the USA, whereas the opposite pattern holds in the UK.

\section{Research methodology}

Interbank rates correspond to interest rates traded in the interbank market by agents and financial institutions. These are overnight rates, i.e. they are set for one day, but they are expressed as a geometric annual rate, with 252 working days in a year.

Table I shows the interbank rates for each country used in this study, the starting date of each series (the final date is 12/30/2011) and the database used. The interbank rates begin on the first working day of 2000, except for those of China and South Africa (due to database limitations).

The time series of interbank rates that comprise the sample are all annual daily overnight rates (for 252 working days) and were transformed into daily rates per working day (used as the daily return), calculated as follows:

$$
I R_{w d}=\left[\left(1+I R_{\text {over }}\right)^{\frac{1}{252}}-1\right]
$$

where $I R_{w d}$ represents the interbank rate of a working day and $I R_{\text {over }}$ the overnight interbank rate.

\begin{tabular}{llll}
\hline Country & Rates interbank interest & Start date & Database \\
\hline Brazil & CDI & $03 / 01 / 2000$ & Economática $^{\circledR}$ \\
Russia & TIRUSSIA & $01 / 08 / 2000$ & The Central Bank of the Russian Federation $^{(\mathrm{d})}$ \\
India & MIBOR & $03 / 01 / 2000$ & Reserve Bank of India $^{(\mathrm{e})}$ \\
China & SHIBOR & $08 / 10 / 2006$ & Shanghai Interbank Offered Rate $^{(\mathrm{f})}$ \\
South Africa & SABOR & $28 / 08 / 2007$ & South Africa Reserve Bank $^{(\mathrm{g})}$ \\
Argentina & BAIBOR & $03 / 01 / 2000$ & Central Bank of Argentina $^{(\mathrm{a})}$ \\
Chile & TICHILE & $09 / 08 / 2001$ & Central Bank of Chile $^{(\mathrm{b})}$ \\
Mexico & TIIE & $05 / 01 / 2000$ & Central Bank of México $^{(\mathrm{c})}$ \\
USA & Federal Funds & $02 / 01 / 2000$ & Federal Reserve $^{(\mathrm{h})}$ \\
Japan & TMIR & $04 / 01 / 2000$ & Bank of Japan $^{(\mathrm{i})}$ \\
Germany & EURIBOR & $04 / 01 / 2000$ & Deutsche Bundesbank $^{(\mathrm{j})}$
\end{tabular}

Notes: Database sites: ${ }^{(a)}$ www.bcra.gov.ar/; ${ }^{(b)}$ www.bcentral.cl/index.asp; ${ }^{(c)}$ www.banxico.org.mx/; ${ }^{(d)}$ www. cbr.ru/eng/; ${ }^{(\mathrm{e})}$ www.rbi.org.in; $\quad{ }^{(\mathrm{f})}$ www.shibor.org; ${ }^{(\mathrm{g})}$ www.resbank.co.za/; ${ }^{(\mathrm{h})}$ www.federalreserve.gov/; ${ }^{(i)}$ www.boj.or.jp/en/; (j) Www.bundesbank.de (access 1 August 2011 and 30 May 2012)

\section{Interbank interest rates}

105

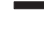


JEFAS

22,42

106
The first procedure adopted is to determine the statistical characteristics of the series studied. For that purpose, the series behaviour and descriptive statistics, such as kurtosis, skewness and distribution, are analysed.

The normality test applied is the Jarque-Bera (JB) test of Jarque and Bera (1987) that tests whether the series of returns follows a normal (Gaussian) distribution. The null hypothesis is that the series follows a normal distribution, which is set against the alternative hypothesis that the series does not follow a normal distribution. The leptokurtic series have heavier tails than a normal distribution because of its sharper central segment.

Next, the autocorrelation and partial autocorrelation tests are performed to determine whether the series is stationary and what type of lag (AR and/or MA) is present. Following this test, unit root tests are performed to assess the stationarity of the series. The most commonly used tests include the augmented Dickey-Fuller (ADF) (Said and Dickey, 1984), Phillips and Perron (1988), Dickey-Fuller generalized least squares of Elliot et al. (1996) and Kwiatkowski et al. (1992) tests. In this study, the most used tests in the literature were used, which are the ADF unit root and the Kwiatkowski-Phillips-Schmidt-Shin tests (KPSS) complementary stationarity tests. The assumptions of the tests include the following:

(1) ADF:

HO: There is unit root.

H1: There is no unit root.

(2) KPSS:

HO: The series is stationary.

H1: The series is not stationary.

To reject the null hypothesis in the ADF test, the test statistic value should be outside the $H O$ acceptance region, as given by the significance levels, whereas in the KPSS test, the test statistic value should be within the $\mathrm{HO}$ acceptance region so as not to reject the null hypothesis.

After these tests for identification of the model, the estimation of the ARIMA processes $(p, d, q)$ - and of the ARIMA $(p, q)$ processes in case of $d=0$ - is begun. The series of daily interbank in the models are as follows: $\operatorname{ARIMA}(1,1,0), \operatorname{ARIMA}(1,1,1), \operatorname{ARIMA}(1,1,2)$, ARIMA $(1,1,3)$, ARIMA $(1,1,4)$, ARIMA $(1,1,5)$, ARIMA $(2,1,0)$, ARIMA $(2,1,1)$, ARIMA $(2,1,2)$, ARIMA $(2,1,3)$, ARIMA $(2,1,4)$, ARIMA $(2,1,5)$, ARIMA $(3,1,0)$, ARIMA $(3,1,1)$, ARIMA $(3,1,2)$, ARIMA $(3,1,3)$, ARIMA $(3,1,4)$, ARIMA $(3,1,5)$, ARIMA $(4,1,0)$, ARIMA $(4,1,1)$, ARIMA $(4,1,2)$, ARIMA $(4,1,3)$, ARIMA $(4,1,4)$, ARIMA $(4,1,5)$, ARIMA $(5,1,1)$, ARIMA $(5,1,2)$, ARIMA $(5,1,3)$, ARIMA $(5,1,4)$, ARIMA $(5,1,5)$, ARIMA $(0,1,1)$, ARIMA $(0,1,2)$, ARIMA $(0,1,3)$, ARIMA $(0,1,4)$ and ARIMA $(0,1,5)$. In the case of the South African series, all models are estimated as ARIMAs (p, 2, q), with estimates of $p$ and $q$ from 0 to 5 . The terms $\mathrm{AR}(p)$ and $\mathrm{M}(q)$ of all series are added according to their significance.

Then, the best ARIMA $(p, d, q)$ or ARIMA $(p, q)$ processes, those deemed more efficient for detection tests of GARCH processes, are chosen using the following criteria: the lowest values of each of the Bayesian information criterion (BIC) or Schwarz Bayesian criterion, the Hanna-Quinn information criterion (HQ) and the Akaike information criterion (AIC) and the standard error of the equation and the significance of the equation parameters.

One of the most important tests when the series are modelled by an ARCH process was performed, which is the ARCH - Lagrange multiplier (ARCH-LM) test, proposed by Engle (1982). If the $T R^{2}$ variable (where $T$ is the number of observations) exceeds the $\chi 2$ statistic, 
the null hypothesis of no autoregressive conditional heteroscedasticity is rejected (Gujarati, 2006), thus showing that the errors have an ARCH structure.

To select the best ARCH (q) - GARCH (p, q) model, the following requirements were posited: correct the heteroscedasticity present in the model, have the largest possible number of significant parameters (at the 1,5 and 10 per cent significance levels) and show the lowest values of the BIC, HQ, AIC information criteria and standard error of the variance equation.

After selecting the best model, the estimated volatilities were plotted and explained qualitatively with respect to the causes for their increase in the return series.

\section{Volatility of interbank rates}

Figure 1 shows the time evolution plots of nominal interbank interest rates for all countries in the sample, emerging and developed, in accordance with the time window for each country. Because the rates are nominal, there are considerable differences in their movements over time, given that inflation is present in the rate.

All series required differencing to become stationary. Only the series of the South African interbank rate required two differences, whereas all others were differenced only once.

Figure 2 shows the time series plots of different interchange rates that are represented by D (SERIES), which indicates one difference. Only the South African series is represented as D [D (SERIES)], indicating two differences. Because all series of the interbank rates were estimated on differences, it was necessary to work with the real series, i.e. without inflation.

All series of differences in interbank rates oscillate around zero, have points of higher lows and higher highs and occur in clusters, suggesting autoregressive conditional heteroscedastic behaviour. Table II shows the descriptive statistics of the series of the differentiated daily interbank rates of emerging and developed countries.

Corroborating the results of the differentiated series plots, descriptive statistics show that all the calculated means are near zero. The kurtosis value for all series is also high, which demonstrates that the error of the conditional-mean equation has a leptokurtic distribution, such as the Student's $t$ distribution. The series that showed the highest excess kurtosis was the interbank rate in Argentina, D [Buenos Aires Interbank Offered Rate (BAIBOR)], 496.90, followed by the series in India, D [Mumbai Interbank Offered Rate (MIBOR)], 447.02. By contrast, the series of daily interbank rates that showed that the lower kurtosis measurements were the European, D [Euro Interbank Offered Rate (EURIBOR)], representing Germany, with a value of 19.65, and the Mexican, D [Tisa de Interés Interbancaria de Equilibrio tasa de interés interbancaria de equilibrio (TIIE)], 36.99. All series reject the null hypothesis of normality at the 1 and 5 per cent significance levels, according to the JB test, as shown in Table I.

Table III presents the daily interbank series correlograms for one difference and, in the case of South Africa Interbank Offered Rate (SABOR), two differences, as described above.The different series are stationary, which is confirmed in the unit root tests shown in Table IV.

Table IV shows that all the different series, both in emerging countries and developed countries, do not have a unit root in the ADF test at all significance levels (1, 5 and 10 per cent), and none reject the null hypothesis of stationarity in the KPSS test. The exception is the daily interbank rate series of South Africa, which (as one difference) does not reject the null hypothesis at the 10 per cent significance level, and does not reject that same hypothesis at all significance levels when using two differences. 
JEFAS

22,42

108

\subsection{ARCH and GARCH models}

In emerging countries, the ARIMA $(p, d, q)$ processes that best modelled the series of daily interbank rates are the following: $\operatorname{ARIMA}(2,1,3)$, for the $\operatorname{CDI} \operatorname{ARIMA}(3,1,4)$, for Russia Interbank Offered Rate (TIRUSSIA); ARIMA(3, 1, 4), for MIBOR; ARIMA(1, 1, 1), for Shanghai Interbank Offered Rate (SHIBOR); ARIMA (3, 1, 3), for Chile Interbank Offered Rate (TICHILE); $\operatorname{ARIMA}(3,1,4)$, for BAIBOR; ARIMA(4, 1, 5), for TIIE and $\operatorname{ARIMA}(0,2,1)$, for SABOR. Considering the conditional heteroscedasticity tests conducted by ARCH-LM test leads to the finding that all the series of the daily interbank rates of emerging countries exhibited autoregressive conditional heteroscedasticity, which
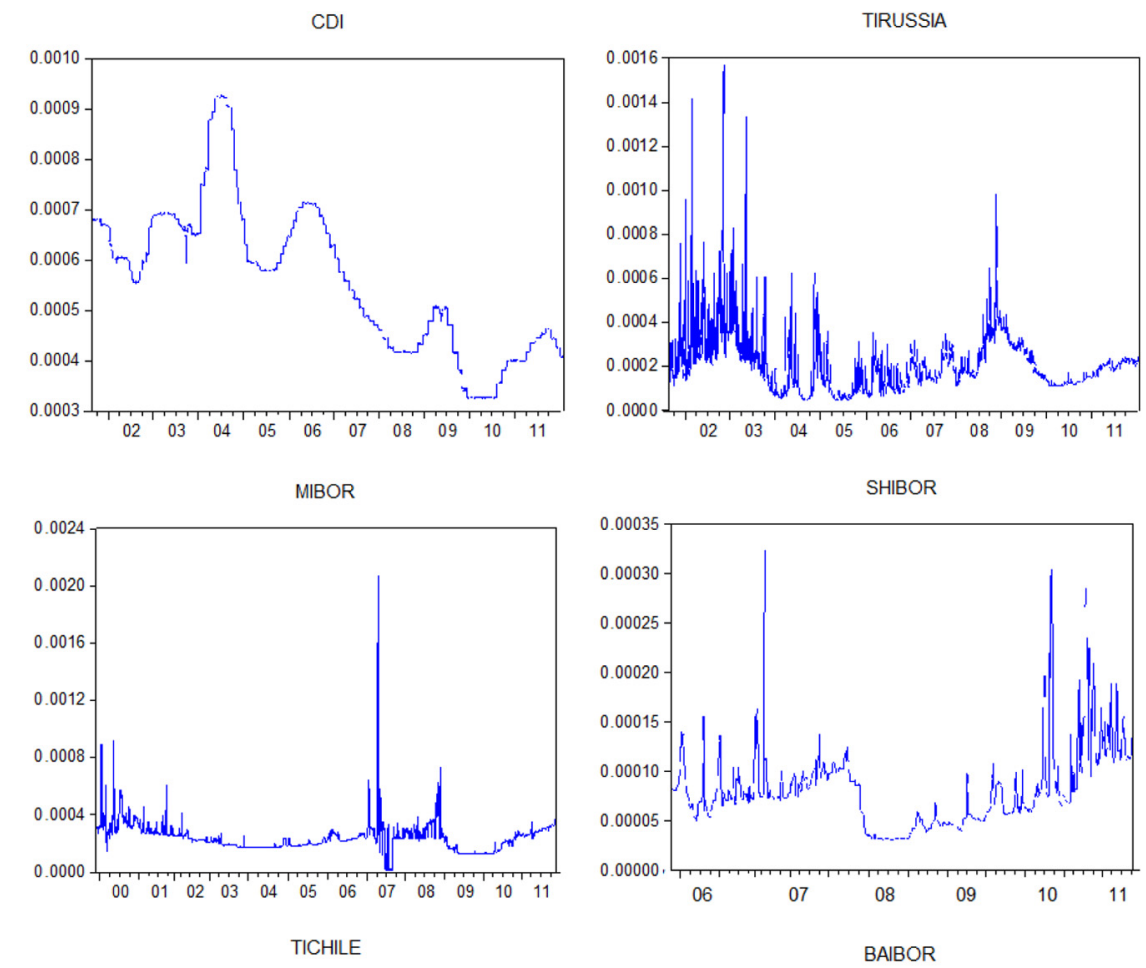

Figure 1.

Evolution of interbank rates
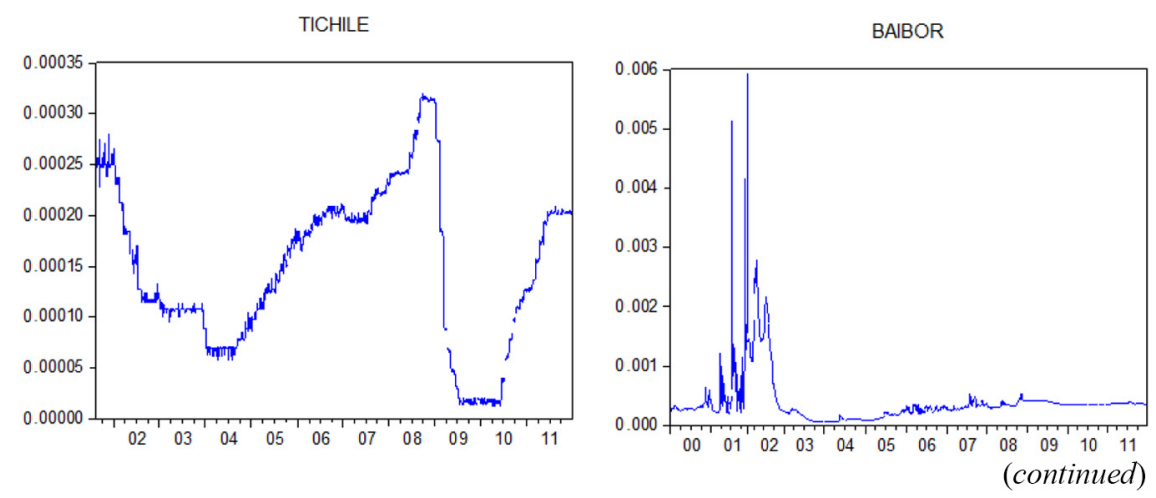

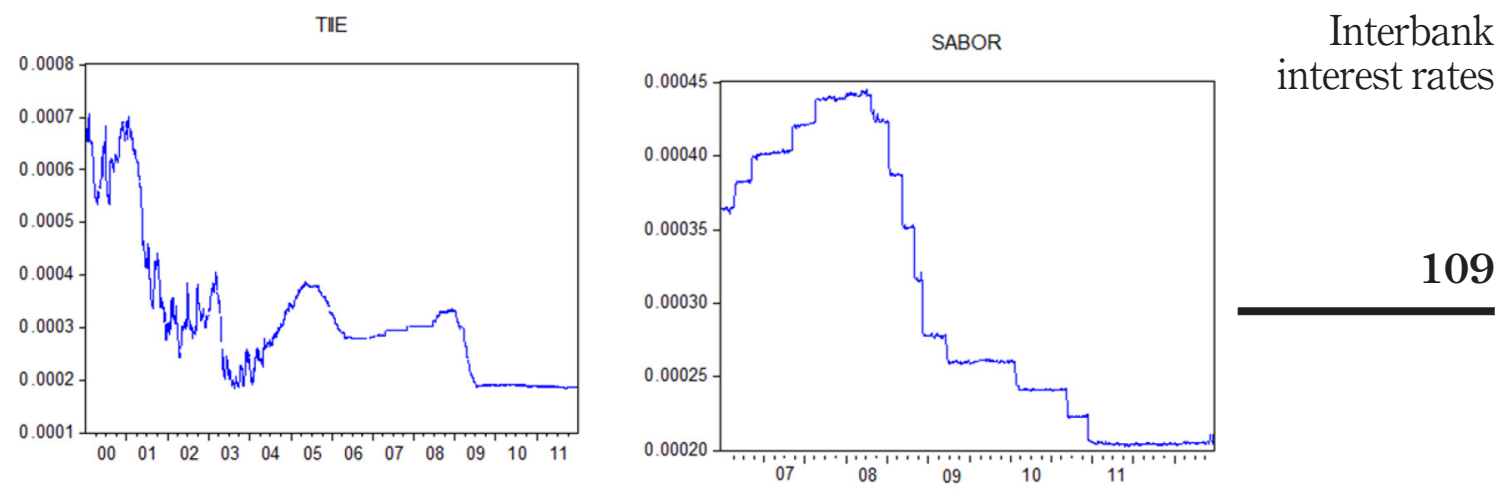

FFUNDS
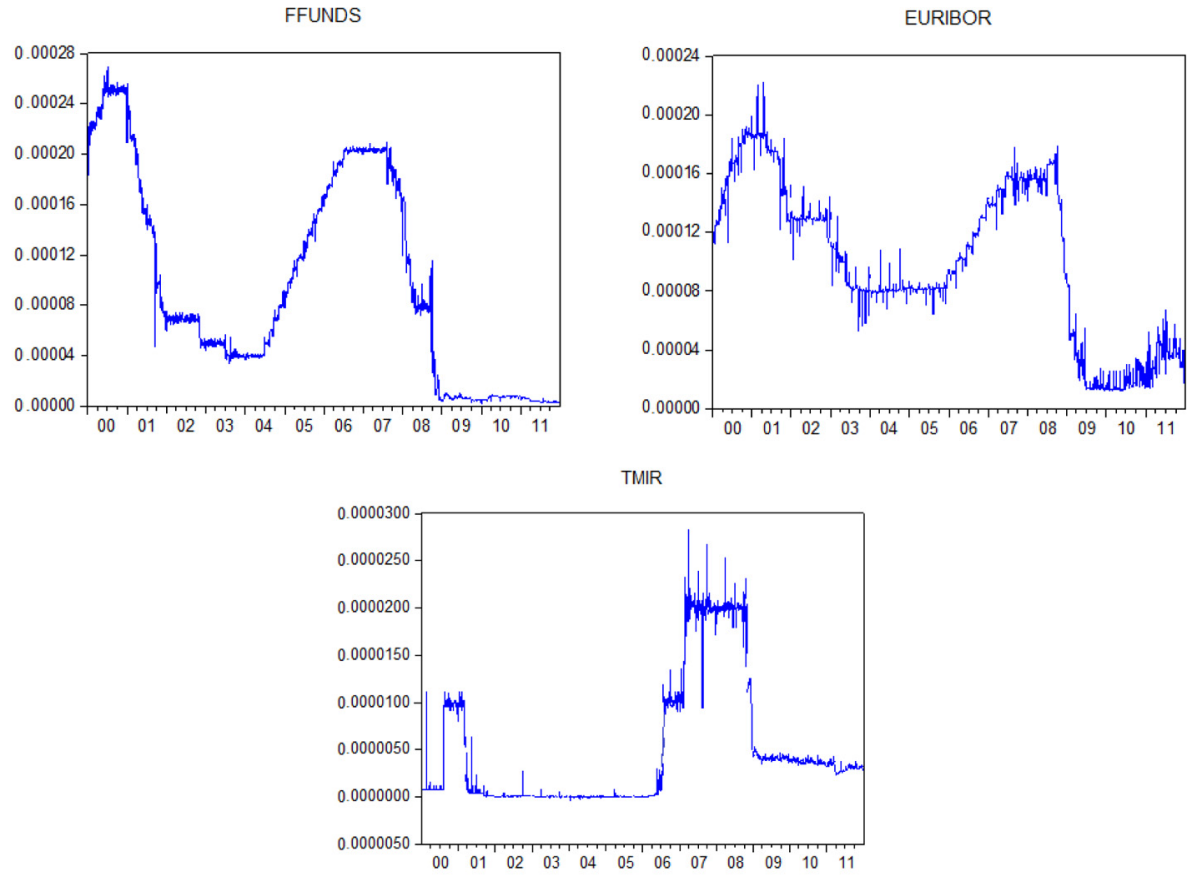

Figure 1.

Source: Own elaboration

allows them to be estimated and modelled by ARCH-GARCH processes. The exception is the CDI and SABOR series shown in Table V, which were not estimated by ARCHGARCH processes and only by ARIMA models because they do not exhibit conditional heteroscedasticity.

The series of the US interbank rate, FFUNDS, was more accurately estimated by an ARIMA $(5,1,5)$ model, the EURIBOR series by an $\operatorname{ARIMA~}(4,1,5)$ model, and the Tokyo Market Interbank Rate (TMIR) series by an ARIMA $(3,1,3)$ model. All series of 
JEFAS

22,42

110

daily interbank rates in developed countries exhibited autoregressive conditional heteroscedasticity.

To select the most efficient ARCH-GARCH models, the following criteria were used: heteroscedasticity correction presented by ARIMA models $(p, d, q)$ by means of the ARCH-LM test; the majority of the parameters must be significant at the 1,5 and 10 per cent levels; and exhibiting low information criteria values (BIC, HQ and AIC) and standard errors. The models "chosen" are shown in Table VI. All series were estimated in
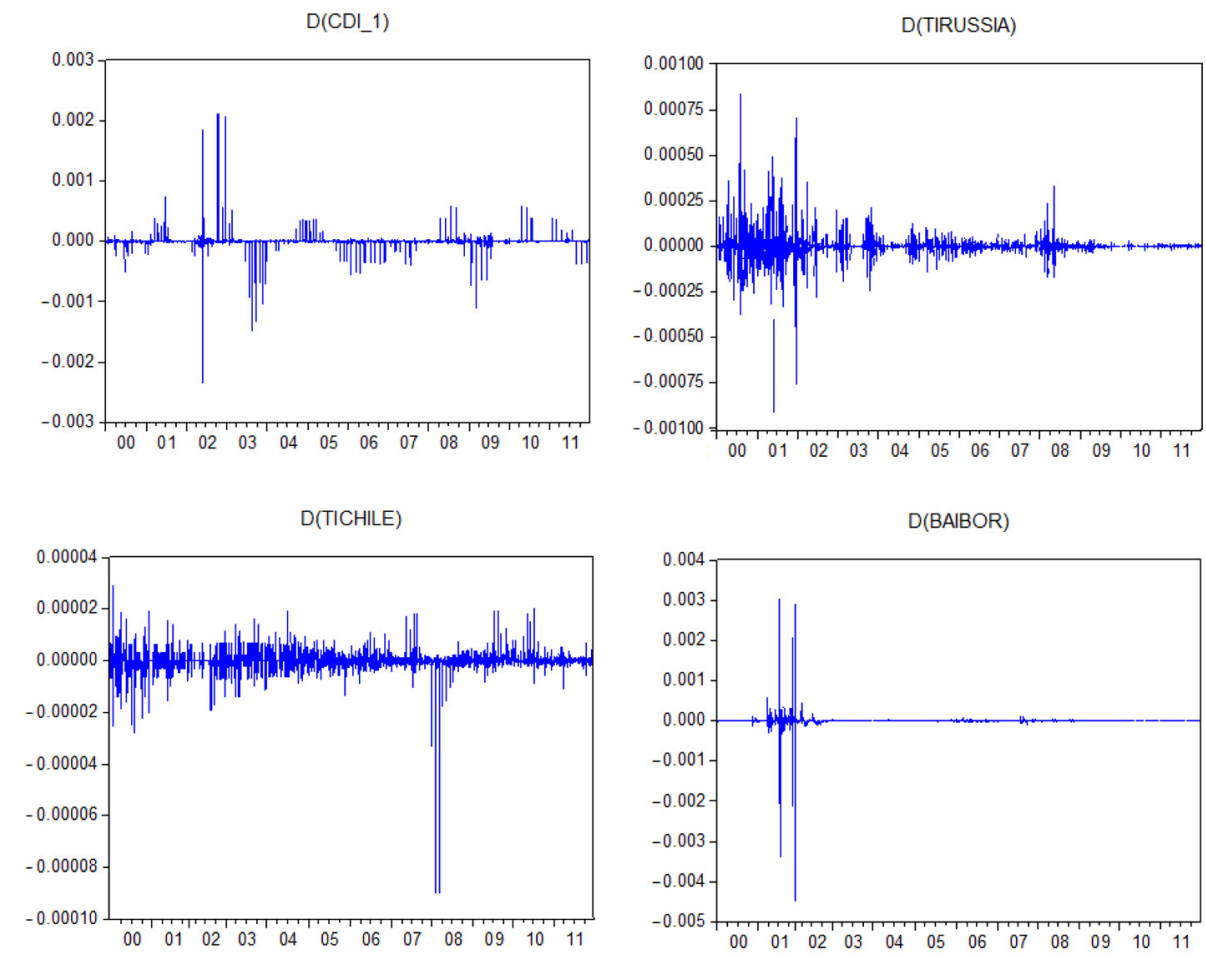

Figure 2.

Time series of returns of interbank rates

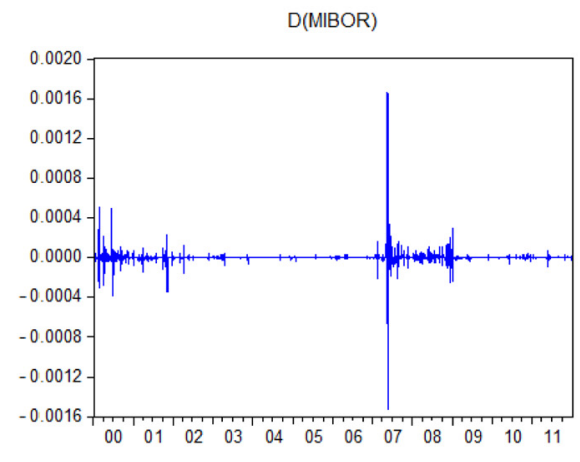



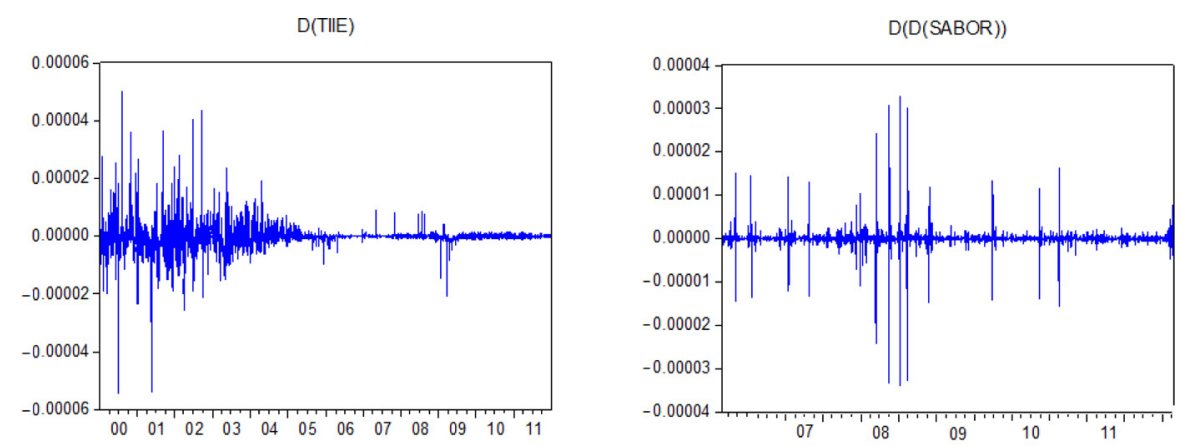

\section{Interbank interest rates}
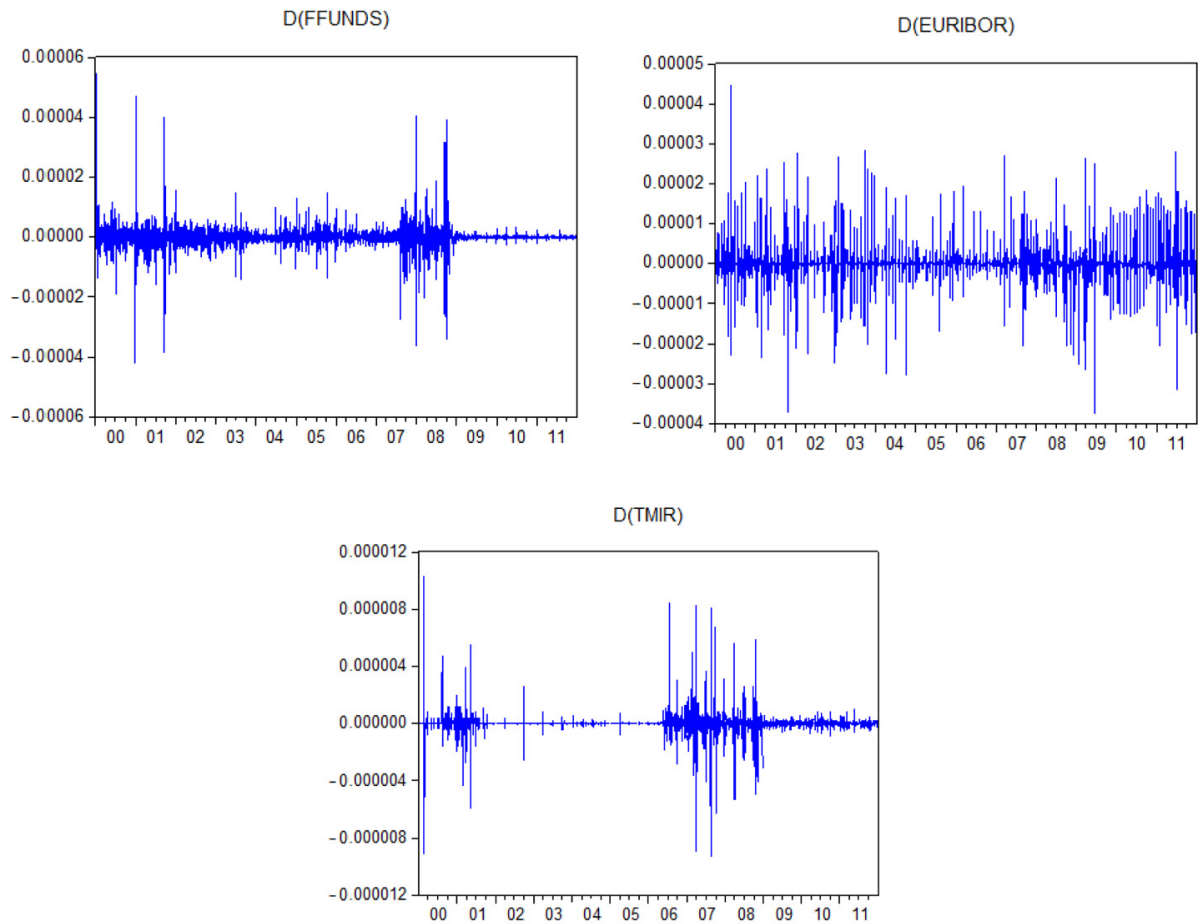

Source: Own elaboration

Figure 2.

$\operatorname{ARCH}(p)$ processes, where $p$ is between 1 and $4, \operatorname{GARCH}(p, q), \operatorname{EGARCH}(p, q), \operatorname{TGARCH}$ $(p, q)$ and $\operatorname{PGARCH}(p, q)$ where $p$ and $q$ from 1 to 2 and threshold order equal to 1 , and in $\operatorname{ARIMA}(p, d, q)-\operatorname{GARCH}(1,1), \operatorname{ARIMA}(p, d, q)-\operatorname{EGARCH}(1,1), \operatorname{ARIMA}(p, d, q)-\mathrm{TARCH}$ $(1,1)$ and $\operatorname{ARIMA}(p, d, q)-\operatorname{PGARCH}(1,1)$ processes. ARIMA $(p, d, q)$ was the previously chosen model for each of the interbank rate series for purposes of modelling the mean and variance together to assess whether these models might be more efficient. However, in the case of a fixed income series, none of the ARIMA-GARCH models were more effective than any of the others. All were estimated in normal and Student's $t$ distributions. 
JEFAS

22,42

112
Table II.

Descriptive statistics of the return series in interbank rates in emerging countries

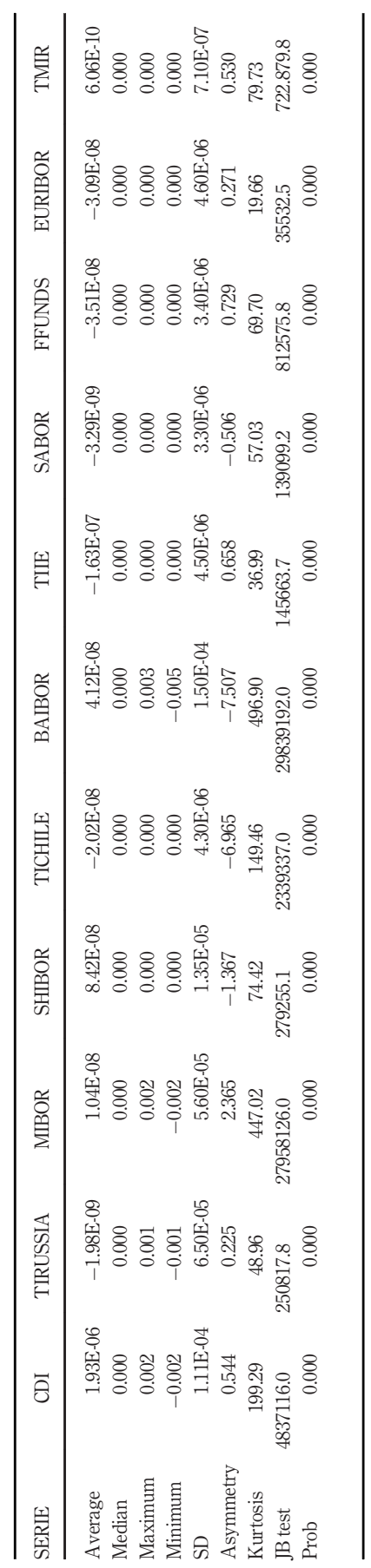




\begin{tabular}{|c|c|c|c|c|c|c|c|c|}
\hline & $\mathrm{AC}$ & $\mathrm{PAC}$ & & $\mathrm{AC}$ & $\mathrm{PAC}$ & $Q$-Stat & Probability & $\begin{array}{l}\text { dilk } \\
\text { ates }\end{array}$ \\
\hline \multirow[t]{10}{*}{ CDI } & | | & | | & 1 & 0.045 & 0.045 & 60898.000 & 0.014 & \\
\hline & | & 10 & 2 & 0.011 & 0.009 & 64633.000 & 0.039 & \\
\hline & i i & ii & 3 & -0.004 & -0.005 & 65100.000 & 0.089 & \\
\hline & i i & i i & 4 & -0.015 & -0.015 & 71973.000 & 0.126 & \\
\hline & i | & i & 5 & -0.009 & -0.008 & 74440.000 & 0.190 & \\
\hline & 11 & 11 & 6 & 0.008 & 0.009 & 76177.000 & 0.267 & 113 \\
\hline & i i & ii & 7 & -0.005 & -0.005 & 76860.000 & 0.361 & \\
\hline & i i & ii & 8 & -0.002 & -0.002 & 76961.000 & 0.464 & \\
\hline & i i & i i & 9 & -0.002 & -0.002 & 77044.000 & 0.564 & \\
\hline & i | & i & 10 & 0.002 & 0.002 & 77113.000 & 0.657 & \\
\hline \multirow[t]{10}{*}{ TIRUSSIA } & $j * 1$ & |* i & 1 & 0.123 & 0.123 & 45843.000 & 0.000 & \\
\hline & $* * \mid 1$ & $* *||$ & 2 & -0.323 & -0.343 & 363.170 & 0.000 & \\
\hline & $* \mid 1$ & $*||$ & 3 & -0.167 & -0.082 & 447.980 & 0.000 & \\
\hline & $1 \mid$ & $i i$ & 4 & 0.038 & -0.042 & 452.300 & 0.000 & \\
\hline & $1 * 1$ & i i & 5 & 0.082 & 0.000 & 472.850 & 0.000 & \\
\hline & | 1 & i & 6 & 0.016 & -0.009 & 473.640 & 0.000 & \\
\hline & $* \mid 1$ & $* i$ & 7 & -0.167 & -0.167 & 558.650 & 0.000 & \\
\hline & $* i j$ & $* i j$ & 8 & -0.135 & -0.099 & 614.010 & 0.000 & \\
\hline & $1 \mid$ & $* i$ & 9 & 0.017 & -0.068 & 614.900 & 0.000 & \\
\hline & | | & | | & 10 & 0.071 & -0.045 & 630.160 & 0.000 & \\
\hline \multirow[t]{10}{*}{ MIBOR } & $* * *$ & $|* * *|$ & 1 & -0.409 & -0.409 & 569.570 & 0.000 & \\
\hline & 11 & $*||$ & 2 & 0.073 & -0.113 & 587.730 & 0.000 & \\
\hline & $*||$ & $* \mid$ i & 3 & -0.122 & -0.165 & 638.720 & 0.000 & \\
\hline & | & $* \mid$ i & 4 & 0.026 & -0.107 & 641.060 & 0.000 & \\
\hline & $* \mid 1$ & $* i i$ & 5 & -0.079 & -0.151 & 662.460 & 0.000 & \\
\hline & $1 \mid$ & $* \mid$ i & 6 & -0.035 & -0.191 & 666.640 & 0.000 & \\
\hline & $|* *|$ & |* & 7 & 0.231 & 0.148 & 848.120 & 0.000 & \\
\hline & $* 11$ & 11 & 8 & -0.107 & 0.040 & 887.260 & 0.000 & \\
\hline & $1 \mid$ & $* \mid$ | & 9 & -0.029 & -0.078 & 890.180 & 0.000 & \\
\hline & $* 11$ & $* \mid$ i & 10 & -0.071 & -0.115 & 907.200 & 0.000 & \\
\hline \multirow[t]{10}{*}{ SHIBOR } & || & | | & 1 & -0.009 & -0.009 & 0.114 & 0.736 & \\
\hline & $* \mid 1$ & $* \mid 1$ & 2 & -0.067 & -0.067 & 60690.000 & 0.048 & \\
\hline & 11 & i i & 3 & 0.044 & 0.043 & 85827.000 & 0.035 & \\
\hline & | | & i & 4 & -0.005 & -0.009 & 86119.000 & 0.072 & \\
\hline & $* \mid 1$ & $* \mid$ | & 5 & -0.111 & -0.106 & 24763.000 & 0.000 & \\
\hline & 11 & i i & 6 & -0.053 & -0.058 & 28492.000 & 0.000 & \\
\hline & i i & ii & 7 & -0.013 & -0.029 & 28727.000 & 0.000 & \\
\hline & $*||$ & $* \mid$ | & 8 & -0.111 & -0.112 & 44930.000 & 0.000 & \\
\hline & | 1 & | & 9 & -0.054 & -0.060 & 48810.000 & 0.000 & \\
\hline & | | & $* \mid$ i & 10 & -0.038 & -0.070 & 50760.000 & 0.000 & \\
\hline \multirow[t]{10}{*}{ TICHILE } & $*||$ & $* \mid$ i & 1 & -0.148 & -0.148 & 61006.000 & 0.000 & \\
\hline & $1 \mid$ & $*||$ & 2 & -0.047 & -0.071 & 67223.000 & 0.000 & \\
\hline & | & | | & 3 & 0.008 & -0.010 & 67400.000 & 0.000 & \\
\hline & i i & $i i$ & 4 & -0.011 & -0.015 & 67719.000 & 0.000 & \\
\hline & i i & i i & 5 & 0.006 & 0.003 & 67831.000 & 0.000 & \\
\hline & 1 & | & 6 & -0.008 & -0.008 & 68001.000 & 0.000 & \\
\hline & i & i i & 7 & 0.006 & 0.004 & 68093.000 & 0.000 & \\
\hline & $\mathrm{i} i$ & i i & 8 & -0.001 & 0.000 & 68094.000 & 0.000 & \\
\hline & | | & i & 9 & 0.013 & 0.014 & 68558.000 & 0.000 & Table III. \\
\hline & 11 & 11 & 10 & -0.005 & -0.001 & 68627.000 & 0.000 & Correlogram of the \\
\hline \multirow[t]{3}{*}{ BAIBOR } & i & 11 & 1 & -0.007 & -0.007 & 0.141 & 0.708 & series returns in \\
\hline & $* * \mid 1$ & $* * \mid 1$ & 2 & -0.266 & -0.266 & 208.100 & 0.000 & interbank rates \\
\hline & & & & & & & (continued) & (differentiated) \\
\hline
\end{tabular}




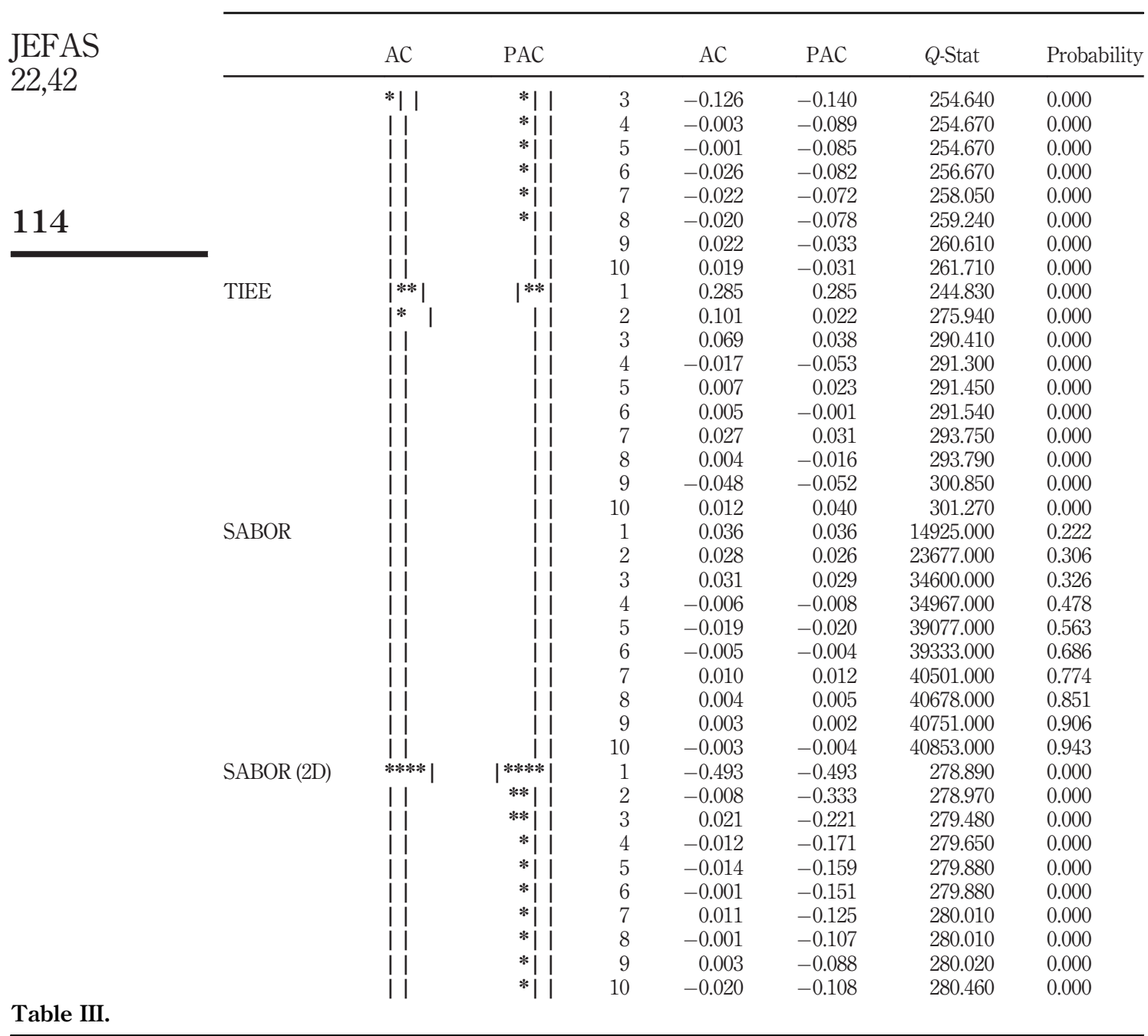

As shown in Table $\mathrm{V}$, only the EURIBOR series exhibits no heteroscedasticity correction as indicated by $T R^{2}$ and $\chi^{2}$ values - because none of the estimated ARCH-GARCH models and extensions could correct the heteroscedasticity presented in the ARIMA $(4,1,5)$ model via the ARCH-LM test. Thus, the model that met the other mentioned criteria was selected as the most efficient model. All other series of daily interbank rates had their conditional heteroscedasticity corrected when modelled by ARCH-GARCH processes, as shown by the ARCH-LM test.

The more efficient ARCH-GARCH processes were better estimated by Student's $t$ distribution, which was expected due to the high kurtosis value in the series.

Of nine series tested (because the $\mathrm{CDI}$ and the SABOR were not estimated in the GARCH models), seven exhibited better results when estimated by EGARCH models, and the other 


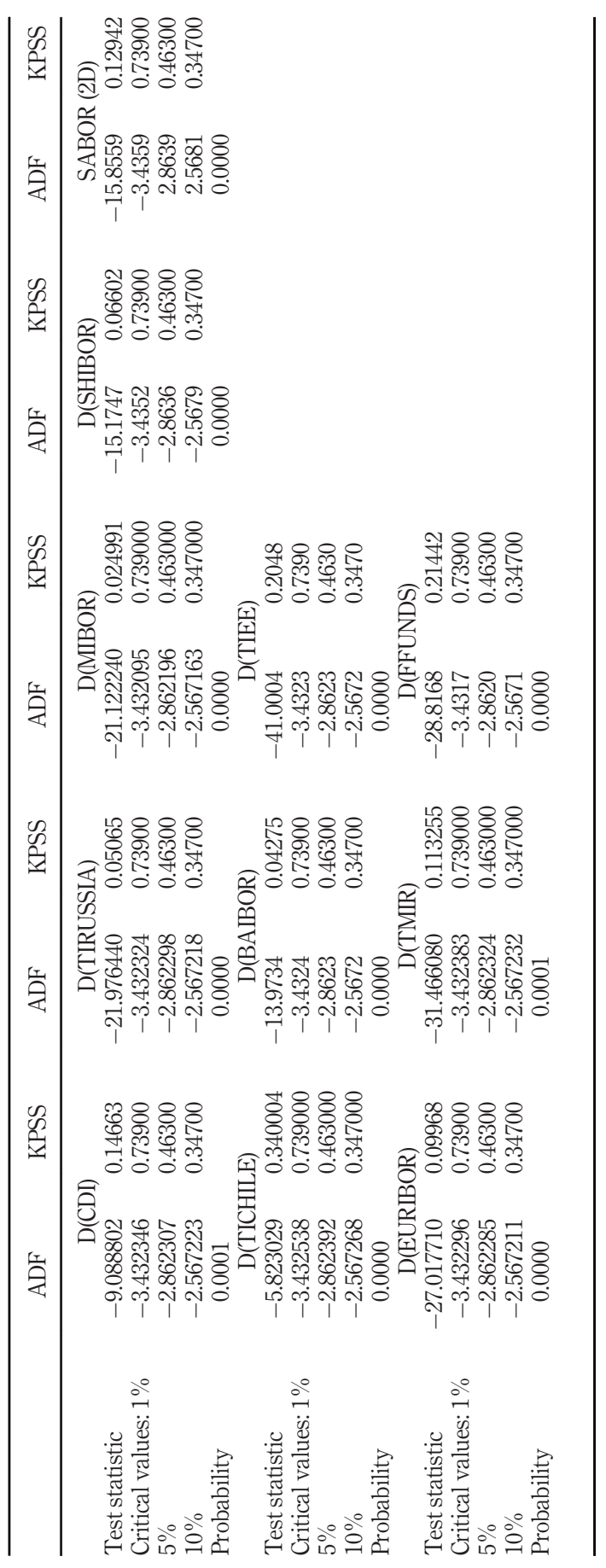

Interbank

115

Table IV. Unit root tests of the return series of interbank rates 
JEFAS

22,42

116

\begin{tabular}{|c|c|c|c|c|c|}
\hline & & & & & LM test \\
\hline & & Coefficient & $p$-value & $T R^{2}$ & Probability $\chi^{2}$ \\
\hline CDI & & ARIMA (2.1.3) & & & \\
\hline & $\theta_{1}$ & 0.2770 & 0.0000 & 0.090 & 0.764 \\
\hline & $\theta_{2}$ & -0.9486 & 0.0000 & & \\
\hline & $\varphi_{1}$ & -0.2331 & 0.0000 & & \\
\hline & $\varphi_{2}$ & 0.9638 & 0.0000 & & \\
\hline TIRUSSIA & $\varphi_{3}$ & $\begin{array}{r}0.0489 \\
\text { ARIMA }(314)\end{array}$ & 0.0105 & & \\
\hline & $\theta_{1}$ & 1.4390 & 0.0000 & 112.024 & 0.000 \\
\hline & $\theta_{2}$ & -1.3585 & 0.0000 & & \\
\hline & $\theta_{3}$ & 0.6158 & 0.0000 & & \\
\hline & $\varphi_{1}$ & -1.3699 & 0.0000 & & \\
\hline & $\varphi_{2}$ & 0.8804 & 0.0000 & & \\
\hline & $\varphi_{3}$ & -0.1790 & 0.0001 & & \\
\hline & $\varphi_{4}$ & -0.2811 & 0.0000 & & \\
\hline MIBOR & & ARIMA (4.1.5) & & & \\
\hline & $\theta_{1}$ & -0.3005 & 0.0000 & 224.000 & 0.000 \\
\hline & $\theta_{2}$ & -0.8166 & 0.0000 & & \\
\hline & $\theta_{3}$ & -0.1904 & 0.0001 & & \\
\hline & $\theta_{4}$ & -0.2841 & 0.0000 & & \\
\hline & $\varphi_{1}$ & -0.2265 & 0.0000 & & \\
\hline & $\varphi_{2}$ & 0.7170 & 0.0000 & & \\
\hline & $\varphi_{3}$ & -0.4009 & 0.0000 & & \\
\hline & $\varphi_{4}$ & 0.1533 & 0.0034 & & \\
\hline & $\varphi_{5}$ & -0.4587 & 0.0000 & & \\
\hline SHIBOR & & ARIMA (1.1.1) & & & \\
\hline & $\theta_{1}$ & $\begin{array}{r}0.8855 \\
-0.9803\end{array}$ & 0.0000 & 166.670 & 0.000 \\
\hline TICHILE & TI & ARIMA (3.1.3) & 0.0000 & & \\
\hline & $\theta_{1}$ & 0.7662 & 0.0000 & 0.882 & 0.348 \\
\hline & $\theta_{2}$ & 0.9834 & 0.0000 & & \\
\hline & $\theta_{3}$ & -0.7614 & 0.0000 & & \\
\hline & $\varphi_{1}$ & -0.9028 & 0.0000 & & \\
\hline & $\varphi_{2}$ & -0.9809 & 0.0000 & & \\
\hline & $\varphi_{3}$ & 0.9037 & 0.0000 & & \\
\hline BAIBOR & & ARIMA (3.1.4) & & & \\
\hline & $\theta_{1}$ & -0.7223 & 0.0000 & 535.456 & 0.000 \\
\hline & $\theta_{2}$ & -0.5030 & 0.0000 & & \\
\hline & $\theta_{3}$ & 0.3970 & 0.0000 & & \\
\hline & $\varphi_{1}$ & 0.6362 & 0.0000 & & \\
\hline & $\varphi_{2}$ & 0.1188 & 0.0000 & & \\
\hline & $\varphi_{3}$ & -0.8405 & 0.0000 & & \\
\hline & $\varphi_{4}$ & -0.2805 & 0.0000 & & \\
\hline TIEE & & ARIMA (4.1.5) & & & \\
\hline & $\theta_{1}$ & -1.6279 & 0.0000 & 27.967 & 0.000 \\
\hline & $\theta_{2}$ & -1.0327 & 0.0000 & & \\
\hline & $\theta_{3}$ & -1.1149 & 0.0000 & & \\
\hline & $\theta_{4}$ & -0.7309 & 0.0000 & & \\
\hline & $\varphi_{1}$ & 1.9167 & 0.0000 & & \\
\hline & $\varphi_{2}$ & 1.5701 & 0.0000 & & \\
\hline & $\varphi_{3}$ & 1.5822 & 0.0000 & & \\
\hline & $\varphi_{4}$ & 1.1837 & 0.0000 & & \\
\hline & & & & & (continued) \\
\hline
\end{tabular}

Table V.

ARIMA Models considered more efficient 


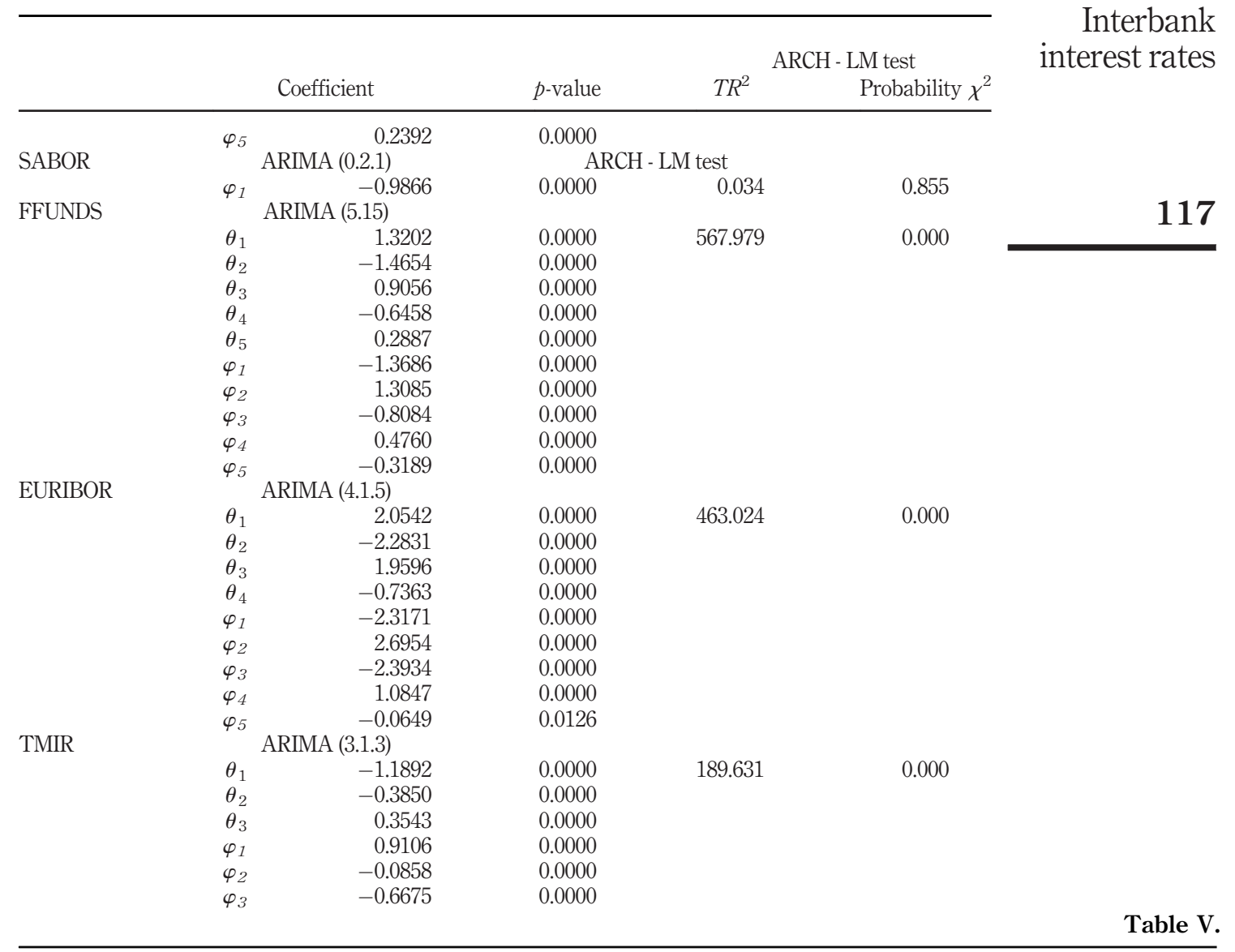

two - TICHILE and BAIBOR - were estimated by ARCH models, demonstrating the skewness in most of the studied series.

The model deemed the most efficient for the daily TIRUSSIA series was the EGARCH (1.2) model; however, the term $\gamma$ had a positive value $(\gamma 0.561, p$-value 0.0000$)$. For the daily SHIBOR series, the EGARCH $(2,2)$ model was the most efficient, with $\gamma$ and $p$-values of 0.08383 and 0.0006 , respectively. Therefore, we cannot state that the volatility in the interbank rates of these countries responds more strongly to negative than positive shocks because the interest rate variable takes longer to respond to shocks than the stock variable, as discussed above; however, as $\gamma$ is non-zero, there are asymmetric impacts. The fact that some of the model parameters are negative does not affect the estimation because the logarithmic specification prevents the variance from being negative, and the model parameters can thus be negative.

The daily MIBOR and TIIE series, which were best estimated by EGARCH (2.2) processes, unlike TIRUSSIA and SHIBOR, exhibited a negative $\gamma$ value $(\gamma-0.10650$, $p$-value 0.0000 , for MIBOR and $\gamma-0.01693$, $p$-value 0.04720 for the TIIE), which suggests 


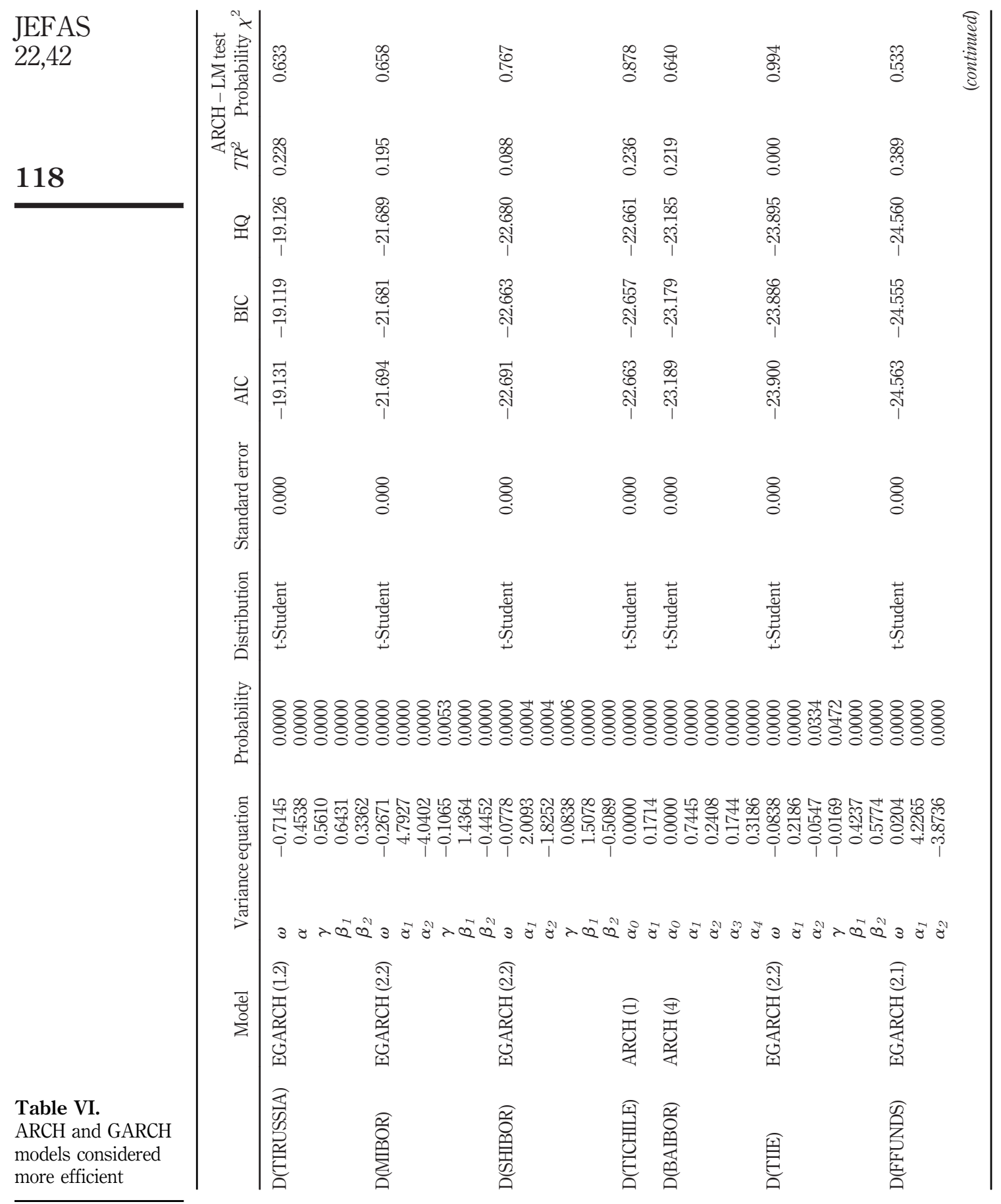




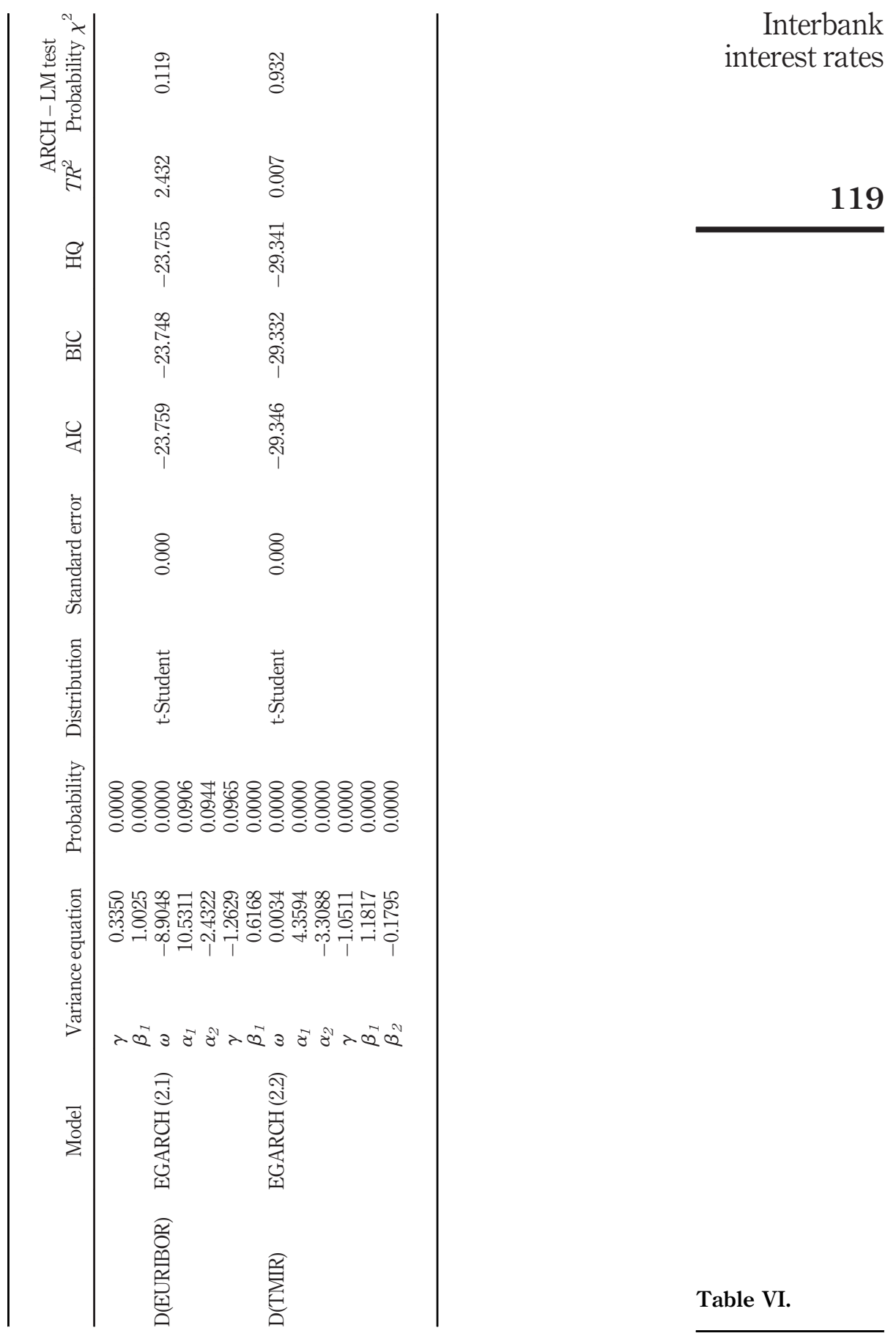


JEFAS

22,42

the presence of the leverage effect in the series (negative shocks increase volatility more than positive shocks). The daily TICHILE and BAIBOR series were the only series that were better estimated by symmetrical and not generalized processes, i.e. ARCH (1) and ARCH (4), respectively, i.e. the series variance depends on the square of past values of its residuals and not on its past variance.

However, in the case of TICHILE series, the EGARCH $(2,2)$ EGARCH $(2,1)$ and EGARCH $(1,1)$ models (t distribution) presented lower information criteria values and standard errors than the ARCH (1) model, but the parameters were not significant, which is not in accordance with the criteria used to select the model.

With respect to developed countries, all series were better modelled by EGARCH processes, namely, EGARCH $(2,1)$ for the FFUNDS and the EURIBOR, and EGARCH $(2,2)$ for TMIR. The EGARCH $(1,2)$ model for the FFUNDS series was the only model of the three series with a positive $\gamma$ value of 0.33496 and a p-value of 0.0000 . For the EURIBOR series, the model presented a $\gamma$ value of -1.26286 with a p-value of 0.0965 ; for the TMIR series, the model presented a $\gamma$ value of -1.05107 and a $p$-value of 0.0000 .

Figure 3 shows the volatility plots calculated using the conditional variances of each GARCH series shown above, for all the interbank rates examined. Although the CDI and SABOR series did not exhibit conditional heteroscedasticity in their ARIMA models and were thus not estimated in the GARCH models for selecting the most efficient model, these series were modelled on a GARCH $(1,1)$ process to facilitate the graphic representation of its volatility. The following series show that, even when the volatility has high peaks, the scale ( $y$-axis) of the plots varies little; however, the peaks are considered.

Regarding the greater volatility points in the interbank rates, these rates correspond to the end of 2002 and the beginning of 2003 (Point 1) due to the presidential elections, which increased the financial risk. However, in the case of interest rates, that was mainly due to the rise in the exchange rate. Since January 1999, when the exchange rate experienced a major devaluation, reaching BRL 1.98 against the dollar, currency devaluations became constant and their peak occurred on the eve of the 2002 presidential election, with an exchange rate of BRL 3.89. This occurrence may explain why the basic interest rate of the Brazilian economy begins 2000 at an annual rate of approximately 17 per cent, is approximately 21 per cent in November 2002, and is 24 per cent per year in January 2003; the rate was beginning to recede during the second half of 2004, dropping to approximately 16 per cent (Point 2) when the exchange rate was approximately BRL 2.90 (Brazilian Central Bank, 2012).

In November 2006, the exchange rate was at approximately BRL 2.17. In subsequent years, there was a gradual reduction in interest rates, reaching an annual rate of 11.18 per cent in 2007, although the rate rose again in 2008 (Point 3) due to the financial crisis. In 2009, the Central Bank Monetary Policy Committee reduced the basic interest rate of the Brazilian economy, which closed the year at 8.65 per cent (Point 4), rising again in 2010. In April 2011, the Sistema Especial de Liquidação e de Custódia (SELIC) rate was set at 11.67 per cent per year, and in April 2013 it was approximately 7.2 per cent p.a. (IPEADATA, 2013).

As for the SABOR series, which is more recent than the others (2007-2011), it showed a higher volatility peak in 2008 when it presented a sharp rise in interest rates mainly due to high inflation. According to IMF report data (2012), in 2006, the average annual inflation rate in South Africa was approximately 4.7 per cent, rising to 7.09 per cent in 2007 and to 11.53 per cent in 2008.

In the interbank rate series in Argentina (BAIBOR), two plots were prepared to better demonstrate the results, given that the series scale changing considerably after 2001 and 
2002, which were years of economic crisis. At the beginning of the decade, the country undertook a series of recessionary and deflationary economic adjustment policies; in 2001, Argentina went through its worst economic crisis since the 1930s that featured a bankrupt financial system, capital flight and restrictions on bank withdrawals. Finally, the country declared a moratorium on private foreign creditors and ended currency convertibility (Vadell, 2006). The peak in years 2006 to early 2008 (Point 6) can be justified due to inflationary pressure, as those were the years when the country's inflation was higher than it had been since the 2001 crisis.
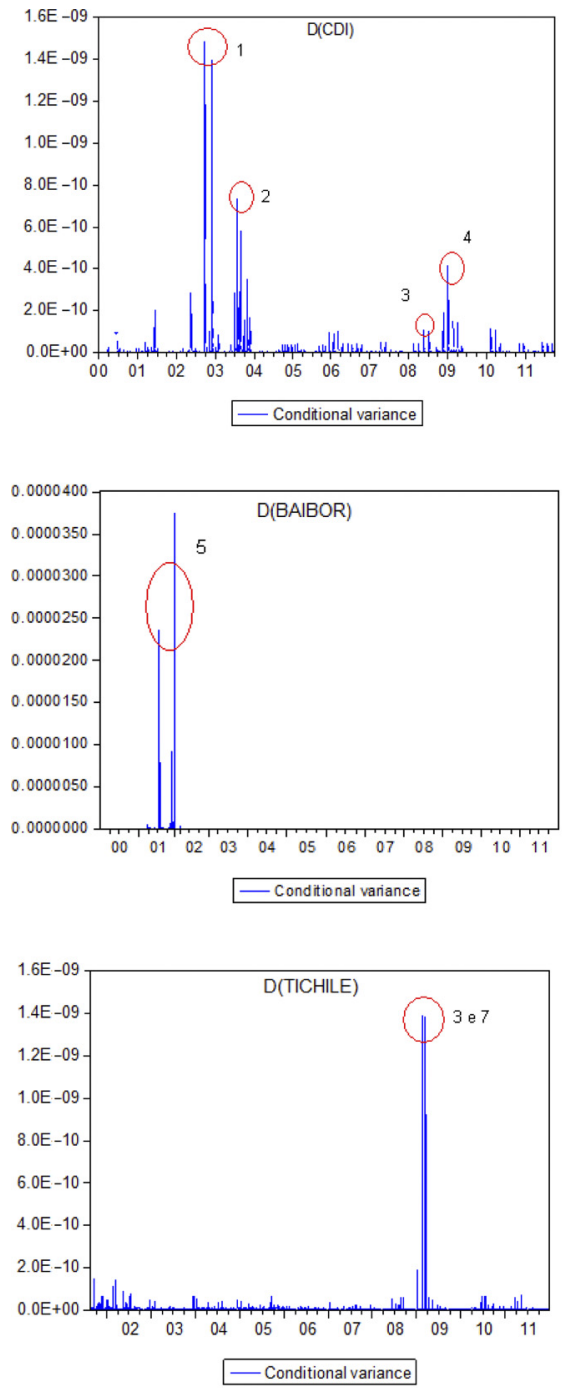
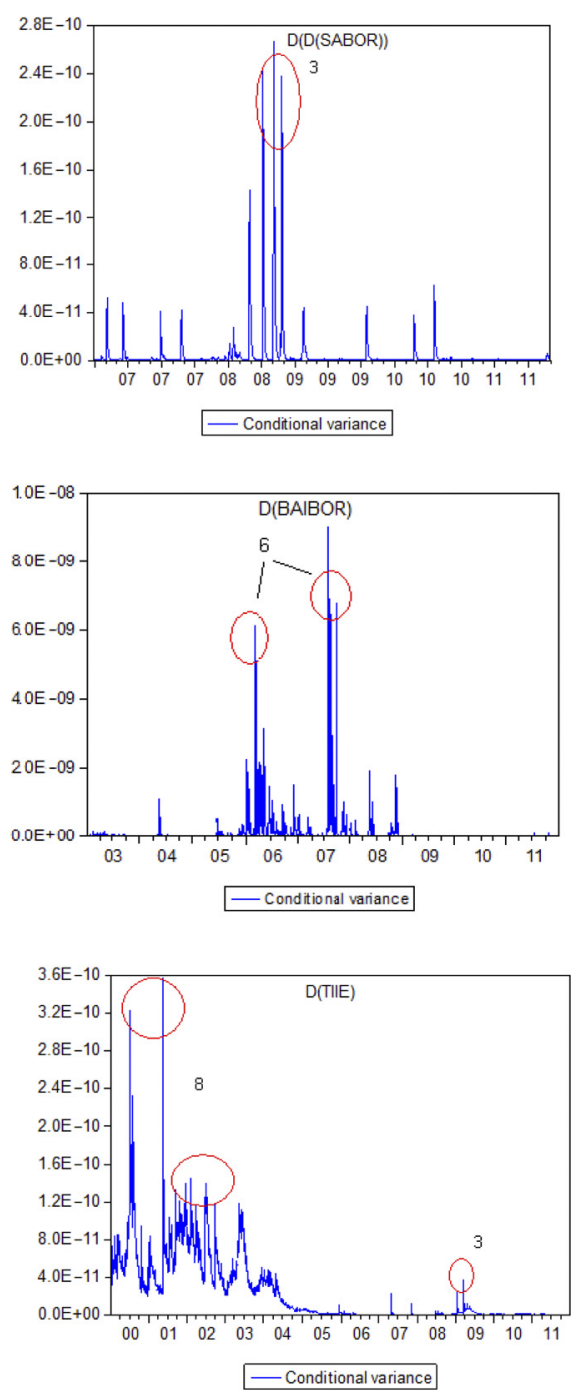

(continued)
Interbank interest rates
Figure 3. Graphics of the volatility of the time series of GARCH processes 

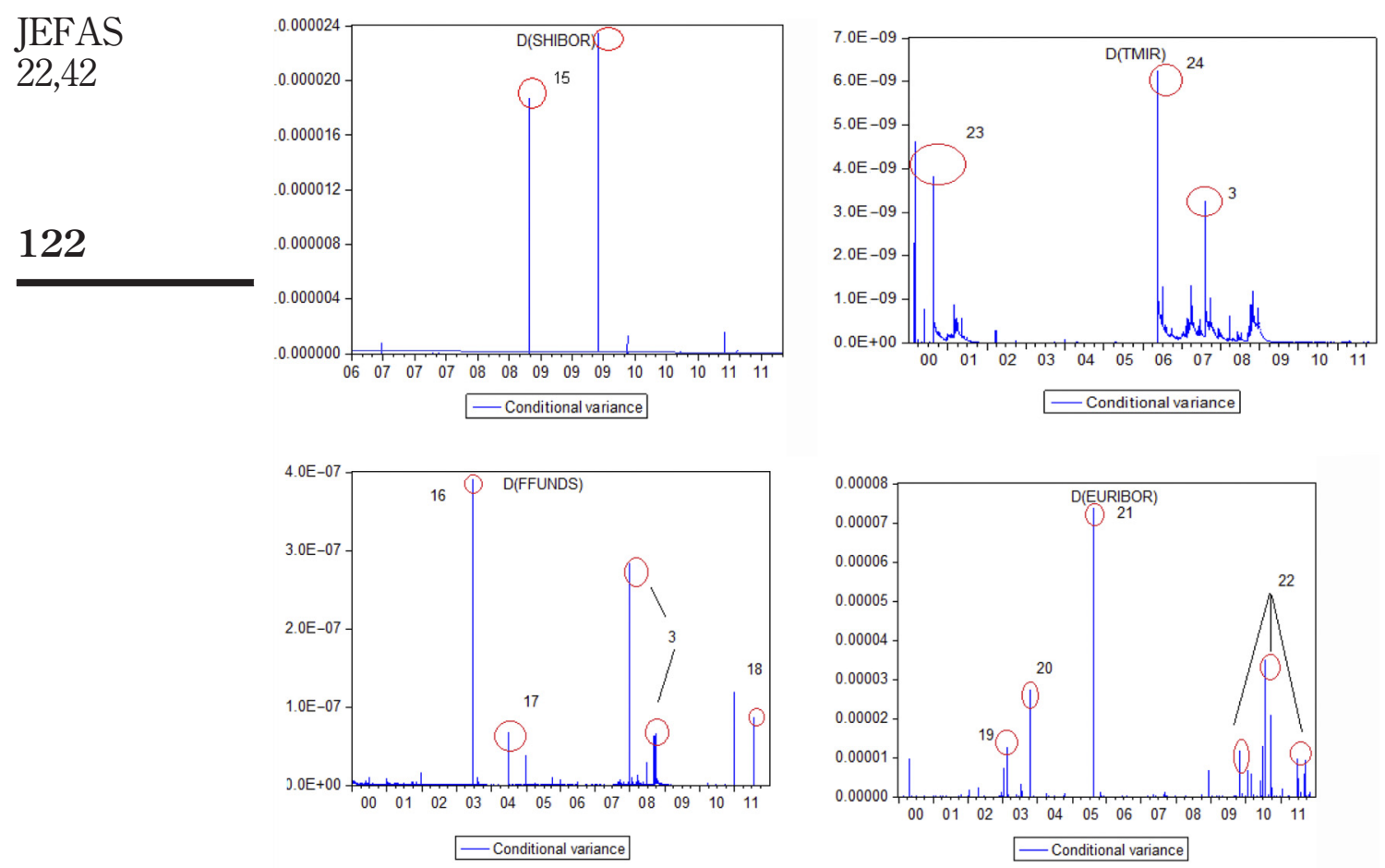

Figure 3.

Source: Own elaboration

Chile has been considered an economic development model among Latin American countries, which is a result not only of a series of favourable economic factors but also of the country's political scenario (return to democratic rule), according to Corrêa and Lima (2008). In 2008 and 2009, Chile experienced higher volatility peaks (Peaks 3 and 7, respectively) because 2008 was the year of the subprime financial crisis, whereas the country had lower credit expansion and deceleration of economic growth in 2009. In addition, 2008 was also the year with the highest inflation rate (8.7 per cent), and 2009 was the worst year of the entire decade in terms of economic growth (-1.693 per cent).

With respect to Mexico, the country began the 2000s with high interest rates (approximately 19 per cent per year) due to high inflation rates that had been recorded since the late 1990s, which increased the volatility of the interbank rate series in 2000 to early 2002 (Point 8).

Russia began 2000 with a strong currency devaluation, an expansion of bank loan policies and high inflation (86 per cent per year in 1999), in addition to an increase in oil and gas prices (Desai, 2006; IMF, 2012), which explains the increased volatility of interest rates in that year (Point 9). In 2002, the government had to resort to a more restrictive monetary policy and greatly increased the interest rate. In 2001, the interbank rate reached an annual rate of 48 per cent, which increased volatility once again (point 10). The same type of event occurred in 2005 (Point 11), although both the increase in inflation and in the interest rate were lower than in previous years. 
In Russia, the monetary policy adopted was different from that in the other BRICS countries. Interest rates increased considerably between October 2008 and September 2009 , which was due to the increased risk aversion of international investors and the sharp fall in prices of commodities (including oil and oil derivatives, according to Acioly et al. (2010).

The opposite trend occurred in India, given that the country began the 2000s with good economic growth and low inflation, albeit with high interest rates (approximately 25 per cent), which may explain the increased volatility represented by point 12 . Between 2000 and 2002, there was a gradual fall in interest rates (between 9 and 12 per cent), which reached an annual rate of approximately 5 per cent by the end of 2002, which may have contributed to a new volatility peak (Point 13). However, in years 2007 and 2009 (Points 3 and 14), the beginning of the global financial crisis followed by the European crisis led to new inflationary pressures in the country. In 2007, the interbank rate peaked at 68 per cent and gradually dropped until 2009.

When analysing China's interbank rate volatility (SHIBOR), only two peaks were found, one in 2008 and another in 2009 (Point 15) (the series consists of the 2006-2011 period only); these peaks are likely a result of the financial crisis in the first year because China is the largest creditor of US Government debt, followed by deflation in the following year.

Following the 2008 crisis, Chinese and Indian interest rates declined faster than the Brazilian rate, as the SELIC began dropping only three months after these other countries, whose drops began in October 2008. However, in Brazil, the reduction extended until July 2009, whereas the Chinese and Indian central banks halted the rate decrease in November 2008 and in February 2009, respectively (Acioly et al., 2010).

These authors add that almost all developed countries and a large number of developing countries adopted less strict monetary policies after the subprime crisis and gradually reduced interest rates, although the evolution of this decrease was different in the two groups of countries. Thus, in developed countries, the drop-in interest rate was more pronounced than in developing countries.

The first major volatility peak in the conditional variance series of the US interbank interest rate (FFUNDS) occurred in 2003 (Point 16), due to a sharp drop in the country's interest rates, which increased again after 2001 and 2002. In 2005 and 2006, there is a gradual rise in interest rates (Point 17) mainly due to the inflationary pressure suffered by the country. The subprime crisis in the US housing market began at the end of 2007, which led to a period of strong economic recession in the following years (2008 and 2009). In August 2011, the USA also faced the rise of the government debt ceiling, a fundamental factor in its payment. After this episode, Standard \& Poor's lowered the credit rating of US bonds from AAA to AA+.

As for the interbank rate in Europe, which is represented by Germany in this study, a member of the European common market, although the market's interest rate is determined by the European Central Bank (ECB). The monetary policy conducted by the ECB occurs through a series of economic policy implementation requirements of the bloc's countries. Points 19 and 20, which represent increases of interbank interest rate volatility in Europe, can be explained by the decline in interest rates that occurred in 2003 and 2004. In the following year (Point 21), there were successive increases in interest rates to curb the beginnings of an inflationary expectation. The Eurozone public debt crisis began at the end of 2009 and early 2010, which led to a sharp drop in interest rates and to an increase in the interbank rate volatility (Point 22). In early 2012, nine European countries exhibited a drop in their credit rating. Nonetheless, Germany retained its AAA rating.

As for the fixed income market of Japan, represented by the TMIR interbank interest rate, the increase in volatility at the beginning of the decade (Point 23), can be assigned to the

\section{Interbank interest rates}

123 
JEFAS

22,42

remnants of the recession faced by the country at the end of the previous decade, with the 1990s being known as the period of the "great recession" or "lost decade" (Mulugetta and Mulugetta, 2009; Hoshi and Kashyap, 2004).

Although countenancing a deflationary scenario in years 2000 and 2001, interest rates were high until mid-2001 and remained at low levels until the end of the first half of 2006, when there was a sharp rise in the rate again (Point 24). In 2007, Japan was among the first countries to feel the early effects of the US financial crisis, and 2008 and 2009 were periods of stagnation and economic recession in the country due to rising interest rates and falling exports (IMF, 2013). According to Miyagawa (2011), the recovery from this shock has been slow, and the government has failed to implement new monetary and tax policies due to the high amount of national debt.

Cosgrove and Marsh (2010) reveal that the combination of a "loose" tax policy, together with a strict monetary policy, led Japan to slow growth, followed by unemployment, deflation and increased national debt.

\section{Final considerations}

This study analysed the volatility of the fixed income market returns of 11 countries, namely, Brazil, three other markets that represent Latin American countries (Argentina, Chile and Mexico), the other countries that make up the so-called "BRICS" (Russia, India, China and South Africa) and three developed countries (USA, Germany and Japan), from January 2000 to December 2011.

This study also aimed to define which of the autoregressive conditional heteroscedasticity models (ARCH, GARCH, EGARCH, TGARCH and PGARCH), and a combination of these with ARIMA models, could more efficiently model the volatility of returns in these markets. The variables used in this study were the daily interbank rates returns as representative of the fixed income market, as interest rates are considered the main instrument of monetary policy of a country.

The volatility peaks of the daily interbank interest rates showed idiosyncratic patterns in each country involved in the study because they are derived from the economic policies adopted for the gross national product growth. In Brazil, for example, high volatility is given by high financial risk in period of presidential elections and periods of high exchange devaluation. In Argentina, the large increase was due to the economic crisis of 2001 and Europe, the Euribor rate showed inflation peaks in the late 2000 due to the public debt of the eurozone crisis.

That is, only in 2008 that there was a peak point in common seen among all countries in the sample with the global financial crisis, all other volatility peak points in the fixed income market are related to inflation containment policies, growth acceleration or exchange rate policies adopted in each country.

In relation to the volatility models used, the $\mathrm{CDI}$ and $\mathrm{SABOR}$ showed no $\mathrm{ARCH}$ behaviour in their series; therefore, these interbank rates were estimated only with ARIMA models. Most other series of daily interbank rates were better estimated by EGARCH models, including the series of developed countries.

Only the Chilean and Argentine rate series were better modelled in ARCH processes. This finding suggests that asymmetric models estimate the interest rate volatility more efficiently than symmetric models, which confirms the study of Edwards and Susmel (2003) and Ke et al. (2008), because negative events increase volatility more than positive events, and the volatility of the interest rate market seems to be short-lived and to behave in a more timely manner than other markets, as it rises at some point and thereafter already returned to their previous levels. 
One limitation to this study was not having found an interbank interest rate database from China and South Africa with the same time span of the other rates studied. Nonetheless, it is expected that this study has contributed to a better understanding of the volatility of interest rates and the main factors affecting this market.

\section{References}

Acioly, L., Chernavsky, E. and Leão, R. (2010), “Crisis internacional: medidas de políticas de países selecionados [International crisis: policy measures of selected countries]", Brasilia: Boletim de Economia e Politica Internacional [Brasilia: International Economy and Policy Bulletin], IPEA, p. 1.

Alberg, D., Shalit, H. and Yosef, R. (2008), "Estimating stock market volatility using asymmetric GARCH models", Applied Financial Economics, Vol. 18, pp. 120-1208.

Alexander, C. (2005), Modelos De Mercado: um Guia Para Análise de Informações Financeiras [Market Models: a Guide for Financial Information Analysis], BM\&F/Saraiva, São Paulo.

Andritzky, J.R., Bannister, G. and Tamirisa, N. (2007), "The impact of macroeconomic announcements on emerging market bonds", Emerging Markets Review, Vol. 8 No. 1, pp. 20-37.

Baillie, R.T., Bollerslev, T. and Mikkelsen, H.O. (1996), "Fractionally integrated generalized autoregressive conditional heteroskedasticity", Journal of Econometrics, Vol. 74 No. 1, pp. 3-30.

Brazilian Central Bank (2012), "Interest rate history", available at: www.bcb.gov.br/?COPOMJUROS, (accessed 15 December 2012).

BM\&FBOVESPA (2011), "São Paulo stock exchange”, available at: www.bmfbovespa.com.br (accessed 7 August 2011).

Bollerslev, T. (1986), "Generalized autoregressive conditional heterocedasticity", Journal of Econometrics, Vol. 31, pp. 307-327.

Bollerslev, T., Engle, R.F. and Wooldridge, J.M. (1998), “A capital asset pricing model with time varying covariances", Journal of Political Economy, Vol. 96 No. 1, pp. 116-131.

Bollerslev, T. (2008), "Glossary to ARCH (GARCH)”, Creates Research Paper No. 49, pp. 1-46.

Corrêa, D. and Lima, G.T. (2008), "Reformas institucionais e crescimento econômico: a experiência Chilena [institutional reforms and economic growth: the Chilean experience]", Revista de Desenvolvimento Econômico, Vol. 10 No. 17, pp. 83-91.

Cosgrove, M. and Marsh, D. (2010), "Lessons from Japan”, International Business \& Economics Research Journal, Vol. 9 No. 5, pp. 95-101.

Dacorogna, M.M., Müller, U.A., Pictet, O.V. and Olsen, R.B. (1998), "Modelling short term volatility with GARCH and HARCH models", in Dunis, C. and Zhou, B. (Eds), Nonlinear Modeling of High Frequency Financial Time Series, Wiley.

Desai, P. (2006), "Why is Russian GDP growth slowing?", The American Economic Review, Vol. 96 No. 2, pp. 342-347.

Dihn, T.H. and Nguyen, D.K. (2008), "The global and regional factors in the volatility of emerging sovereign bond markets", American Journal Finance and Accounting, Vol. 1 No. 1, pp. 52-68.

Ding, Z., Granger, C.W.J. and Engle, R.F. (1993), “A long memory property of stock market returns and a new model”, Journal of Empirical Finance, Vol. 1 No. 1, pp. 83-106.

Edwards, S. and Susmel, R. (2003), "Interest-rate volatility in emerging markets", The Review of Economics and Statistics, Vol. 85 No. 2, pp. 328-348.

Elliot, G., Rothenberg, T.J. and Stock, J.H. (1996), "Efficient tests for an autoregressive unit root", The Econometric Society, Vol. 64 No. 4, pp. 813-836.
Interbank interest rates 
JEFAS

22,42

Enders, W. (2004), Applied Econometric Time Series, Iowa State University: John Wiley \& Sons.

Engle, R.F. (1982), "Autoregressive conditional heteroscedasticity with estimates of the variance of united kingdom inflation”, Econometrica, Vol. 50 No. 4, pp. 987-1008.

Engle, R.F. (1990), "Discussion: stock market volatility and the crash of '87", Review of Financial Studies, Vol. 3 No. 1, pp. 103-106.

Engle, R.F. and Kroner, K.F. (1995), "Multivariate simultaneous generalized ARCH”, Economy Theory, Vol. 11 No. 1, pp. 122-150.

Engle, R.F. and Lee, G.G.J. (1999), “A permanent and transitory component model of stock return volatility", in Engle, R.F. and White, H. (Eds), Cointegration, Causality, and Forecasting: A Festschrift in Honor of Clive W.J. Granger, Oxford University Press, pp. 475-497.

Fabozzi, F.J. (2000), Bonds Markets: Analysis and Strategies, Prentice Hall, New Jersey, NJ.

Fama, E.F. (1965), “The behavior of stock-market prices”, The Journal of Business, Vol. 38 No. 1, pp. 34-105.

Gertler, M. and Karadi, P. (2010), "A model of unconventional monetary policy”, Journal of Monetary Economics, Vol. 58 No. 1, pp. 17-34.

Girard, E. and Biwas, R. (2007), "Trading volume and market volatility: developed versus emerging stock markets", The Financial Review, Vol. 42 No. 3, pp. 429-459.

Glosten, L.R., Jagannathan, R. and Runkle, D. (1993), "On the relation between the expected value and the volatility of the nominal excess return on stocks", Journal of Finance, Vol. 48 No. 5, pp. 17791801.

Goeu, P. and Marquering, W. (2004), "Modeling the conditional variance between bonds and stock returns: a multivariate GRACH approach", Journal of Financial Econometrics, Vol. 2 No. 4, pp. 531-564.

Gujarati, D.N. (2006), Econometria Básica [Basic Econometrics], 4th ed., Pearson Makron Books, São Paulo. Haugen, R.A. (1997), Modern Investment Theory, Prentice Hall, New Jersey, NJ.

Higgins, M.L. and Bera, A.K. (1992), "A class of nonlinear ARCH models", International Economic Review, Vol. 33 No. 1, pp. 137-158.

Hoshi, T. and Kashyap, N.K. (2004), "Japan's financial crisis and economic stagnation”, Journal of Economic Perspectives, Vol. 18 No. 1, pp. 3-26.

IMF (International Monetary Fund) (2012), "World economic outlook database”, available at: www.imf. org (accessed 12 October 2012).

IMF (International Monetary Fund) (2013), "World economic outlook database”, available at: www.imf. org (accessed 10 January 2013).

IPEADATA Brazilian Institute of Applied Economic Research (2013), "Macroeconomic, regional and social database", available at: www.ipeadata.gov.br (accessed 15 January 2010, 18 June 2011 and 16 December 2013).

Jarque, C.M. and Bera, A.K. (1987), "A test for normality of observations and regression residuals", International Statistical Review, Vol. 55 No. 2, pp. 163-172.

Karagiannis, S.K., Vlamis, P. and Panagopoulos, Y. (2010), "The emerging BRIC economies: evidence from the interest rate transmission mechanism", Eurasia Business and Economic Society (EBES). Conference, Athens.

Ke, J., Chen, Z. and Zhang, R. (2008), “Comparative analysis of international stock market volatility with ARCH model”, Anais: International Seminar on Future Information Technology and Management Engineering, pp. 494-497.

Krugman, P.R. and Obstfeld, M. (1999), Economia Internacional Teoria e Politica [International Economy: Theory and Policy], 4th ed., Makron Books, São Paulo.

Kwiatkowski, D., Phillips, P.C.B., Schmidt, P. and Shin, Y. (1992), "Testing the null hypothesis of stationarity against the alternative of a unit root", Journal of Econometrics, Vol. 54, pp. 159-178. 
Macit, F. (2012), “Who responds more to monetary policy, conventional banks or participation banks?”, Journal of Economics, Finance and Administrative Science, Vol. 17 No. 33, pp. 10-14.

Mankiw, N.G. (2005), Introdução a Economia [Introduction to Economics], Cengage Learning, São Paulo.

Miyagawa, T. (2011), "Economic slowdown in Japan and the role of intangible assets on the revitalization of the Japanese economy. Research unit for statistical and empirical analysis in social sciences (Hi-Stat)", Discussion Paper Series 162, Institute of Economic ResearchHitotsubashi University.

Müller, U.A., Dacorogna, M.M., Davé, R.D., Olsen, R.B., Pictet, O.V. and Weizsäcker, J.V. (1997), "Volatilities of different time resolutions - analyzing the dynamics of market components", Journal of Empirical Finance, Vol. 4 Nos 2/3, pp. 213-239.

Mulugetta, A. and Mulugetta, Y. (2009), "Labor, capital service, and productivity contributions to national economic growth: focusing on the Japanese case", Global Economy Journal, Vol. 9 No. 3, pp. 1-19.

Nelson, D.B. (1991), “Conditional heteroskedasticity in asset returns: a new approach”, Econometrica, Vol. 59 No. 2, pp. 347-370.

Nguyen, V.B. (2015), "Effects of fiscal deficit and money M2 supply on inflation: evidence from selected economies of Asia", Journal of Economics, Finance and Administrative Science, Vol. 20 No. 38, pp. 49-53.

Phillips, P.C.B. and Perron, P. (1988), "Testing for a unit root in time series regression”, Biometrika, Vol. 75 No. 2, pp. 335-346.

Pinheiro, J.L. (2009), Mercado de Capitais: Fundamentos e Técnicas [Capital Market: Fundamentals and Techniques], Atlas, São Paulo.

Polwitoon, S. and Tawatnuntachai, O. (2008), "Emerging market bond funds: a comprehensive analysis", The Financial Review, Vol. 43, pp. 51-84.

Reilly, F.K., Chan, K.C. and Wright, D.J. (2000), "Bond market volatility compared to stock market volatility", Journal of Portfolio Management, Vol. 27 No. 1, pp. 82-92.

Said, S.E. and Dickey, D.A. (1984), "Testing for unit roots in autoregressive-moving average models of unknown order", Biometrika, Vol. 71 No. 3, pp. 599-607.

Stock, J.H. and Watson, M.K. (2004), Econometria [Econometrics], Addison Wesley, São Paulo.

Taylor, S.J. (2005), Asset Price Dynamics, Volatility, and Prediction, Princeton University Press, Princeton.

Vadell, J.A. (2006), "A política internacional, a conjuntura econômica e a Argentina de Néstor Kirchner [international policy, economic conjuncture and Nestor Kirchner's Argentina]", Revista Brasileira de Politica Internacional, Vol. 49 No. 1, pp. 194-214.

Wet, W.A. (2006), "A structural GARCH model: an application on South African data”, Economic Modelling, Vol. 23, pp.775-791.

Wilmott, P. (2001), Introduces Quantitative Finance, John Wiley \& Sons, Chichester.

World Bank (2011), "Databank", available at: www.worldbank.org (accessed on 10 October 2010, 4 January 2011, 25 March 2011 and 16 May).

Yang, J., Zhou, Y. and Wang, Z. (2009), "The stock-bond correlation and macroeconomic conditions: one and a half centuries of evidence", Journal of Banking \& Finance, Vol. 33, pp. 670-680.

Young, P.J. and Johnson, R. (2002), "Bond market volatility compared with stock market volatility: evidence from the UK", Journal of Asset Management, Vol. 3 No. 2, pp. 101-111.

Young, P.J. and Johnson, R. (2005), "Bond market volatility vs stock market volatility: the Swiss experience", Financial Markets and Portfolio Management, Vol. 18 No. 1, pp. 8-23.

Zakoïan, J.M. (1994), “Threshold heteroskedastic models”, Journal of Economic Dynamics and Control, Vol. 18, pp. 931-955. 
JEFAS

22,42

128

\begin{abstract}
About the authors
Nara Rossetti is an Assistant Professor at the Department of Production Engineering - Federal University of São Carlos - Sorocaba, Brazil. She holds a PhD in Production Engineering at School of Engineering of São Carlos in the University of São Paulo, Brazil.

Marcelo Seido Nagano is an Associate Professor at the School of Engineering of São Carlos in the University of São Paulo, Brazil, where is currently hold the position of Head of the Operations Research Group of the Production Engineering Department. Along with his teaching duties, his research interests refer to decision systems and models in industry and services, including a range of decisions related to the design and optimization of processes, production and planning and scheduling, as well as knowledge management and innovation management as a supporting infrastructure. In these areas, he has carried out several research projects and produced a number of refereed publications. He has some editorial duties; most notably, he is an Editor of the Journal of Engineering and Computer Innovations, and Member of the Editorial Board of International Journal of Industrial Engineering Computations, Management Science Letters and Technology Audit and Production Reserves. He has more than 100 papers published in important journals with impact factors and journal citation reports (JCR), such as European Journal of Operational Research, International Journal of Information Management, Production Planning \& Control, Expert Systems with Applications, Economic Modelling, Journal of Cleaner Production, International Journal of Production Research, Knowledge Management Research and Practice, Engineering Applications of Artificial Intelligence, International Journal of Human Resource Management, Journal of the Operational Research Society, Journal of Materials Processing Technology, Computers \& Industrial Engineering, International Journal, Advanced Manufacturing Technology, etc. Marcelo Seido Nagano is the corresponding author and can be contacted at: drnagano@usp.br

Jorge Luís Faria Meirelles is an Assistant Professor at the Department of Production Engineering Federal University of São Carlos - Sorocaba, Brazil. He holds a PhD in Production Engineering at School of Engineering of São Carlos in the University of São Paulo, Brazil.
\end{abstract}

For instructions on how to order reprints of this article, please visit our website: www.emeraldgrouppublishing.com/licensing/reprints.htm Or contact us for further details: permissions@emeraldinsight.com 